Article

\title{
Co-Production Performance Evaluation of a Novel Solar Combi System for Simultaneous Pure Water and Hot Water Supply in Urban Households of UAE
}

\author{
Nutakki Tirumala Uday Kumar ${ }^{1,2, *}$ and Andrew R. Martin ${ }^{2}$ \\ 1 RAK Research and Innovation Center, American University of Ras Al Khaimah (AURAK), \\ 31208 Ras Al Khaimah, UAE \\ 2 Department of Energy Technology, KTH Royal Institute of Technology, S-100 44 Stockholm, Sweden; \\ andrew.martin@energy.kth.se \\ * Correspondence: uday.kumar@aurak.ac.ae; Tel.: +971-50-1954502
}

Academic Editors: Francesco Calise, Massimo Dentice d'Accadia and Antonio Piacentino Received: 26 October 2016; Accepted: 28 March 2017; Published: 4 April 2017

\begin{abstract}
Water is the most desirable and sparse resource in Gulf cooperation council (GCC) region. Utilization of point-of-use (POU) water treatment devices has been gaining huge market recently due to increase in knowledge of urban population on health related issues over contaminants in decentralized water distribution networks. However, there is no foolproof way of knowing whether the treated water is free of contaminants harmful for drinking and hence reliance on certified bottled water has increased worldwide. The bottling process right from treatment to delivery is highly unsustainable due to huge energy demand along the supply chain. As a step towards sustainability, we investigated various ways of coupling of membrane distillation (MD) process with solar domestic heaters for co-production of domestic heat and pure water. Performance dynamics of various integration techniques have been evaluated and appropriate configuration has been identified for real scale application. A solar combi MD (SCMD) system is experimentally tested for single household application for production $20 \mathrm{~L} /$ day of pure water and $250 \mathrm{~L} /$ day of hot water simultaneously without any auxiliary heating device. The efficiency of co-production system is compared with individual operation of solar heaters and solar membrane distillation.
\end{abstract}

Keywords: solar domestic hot water (SDHW); co-production; membrane distillation (MD); solar combi; thermal storage

\section{Introduction}

Desalination has strategic importance in Middle East and North Africa region as a main source of fresh water. Gulf cooperation council (GCC) countries accounts for 57\% of world's desalination capacity out of which one fourth is produced by UAE [1]. The UAE has become leader in implementing alternative methods for creating fresh water resources through desalination and around $50 \%$ of the desalinated water is used by domestic sector [2]. Although utility distribution authorities state that the desalinated water is safe to drink, more than $90 \%$ of population avoids drinking tap water due to potential health and hygiene concerns [3]. This brings in the big picture of reliance on bottled water by urban population and, in fact, UAE stands as sixth largest per capita bottled water consumer in the world [4]. Desalination itself is high energy consuming process and researchers around the world striving to perfect the process of desalination, making it efficient and cost-effective [5]. However, purifying the municipality supplied desalinated water again for bottling adds on more energy along the conversion chain and the potential environmental impact of plastic waste makes bottling process highly unsustainable [6]. The need for a sustainable approach to reduce reliance on bottled water has 
motivated us to develop a point of use (POU) water purification unit based on Membrane Distillation (MD) technology integrated with renewable energy.

Membrane distillation is a novel process that could be adapted effectively for many water purification applications. Hot-side temperatures below $80^{\circ} \mathrm{C}$ are suitable and this process has been proven ideal for exploiting waste heat or solar thermal resources for small scale applications due to ability of tolerating intermittent and fluctuating conditions [7]. Among various configurations of $\mathrm{MD}$, air gap membrane distillation has been adopted widely by researchers for integration with solar systems. In recent years, several pilot and commercial scale solar driven air gap membrane distillation (AGMD) systems were developed and tested with production capacities ranging from $50 \mathrm{~L} /$ day to $100 \mathrm{~m}^{3}$ /day [8]. Banat et al. [9] developed stand-alone solar desalination systems based on MD to provide potable water in remote areas having abundant solar energy. Spiral wound AGMD modules were developed by Fraunhofer ISE with production capacity of 100, $500 \mathrm{~L} /$ day to $10 \mathrm{~m}^{3} /$ day $[10,11]$. Eight pilot plants were installed in five different countries, i.e., Grand Canaria, Egypt, Jordan, Germany, and Italy. Blanco et al. [12] tested a solar driven multistage flat sheet AGMD module with $9 \mathrm{~m}^{2}$ surface area for desalination with capacities of $0.5 \mathrm{~m}^{3} /$ day to $50 \mathrm{~m}^{3} /$ day. A specific heat consumption of $1400 \mathrm{kWh} / \mathrm{m}^{3}$ with a total maximum distillate production of $20 \mathrm{~L} / \mathrm{h}$ per module was obtained with very less recovery of $2 \%$. A flux of $7 \mathrm{~kg} / \mathrm{m}^{2} \mathrm{~h}$ was obtained with another AGMD integrated into a multistage layout module having total surface area of $2.3 \mathrm{~m}^{2}$ coupled with compound parabolic collector field during solar hours [13]. The multistage MD system proved to be suitable for coupling with transient solar thermal energy but scale-up from laboratory scale affected specific distillate production and thermal consumption [14].

Stand alone solar MD (SMD) can be applied in regions of abundant solar radiation region to produce fresh water but the water costs are still high, because solar thermal source attributes to $70-80 \%$ of total cost [15]. Horta et al. [16] assessed the use of commercial low-temperature solar thermal technologies with different layouts and optimum system dimensioning was studied in terms of water production costs at different locations. They concluded that the costs related with solar energy supply are highly dependent upon specific energy consumption of the MD desalination system. Implementation of standalone solar MD systems may be possible if the cost of PV panels, solar heaters, the membranes and other fixed capital costs items can be reduced. Therefore, integrating MD process into co-generation or poly generation could reduce initial investment compared to standalone MD operation [17].

Integrating multiple thermal processes is one of most efficient ways to augment the energy efficiency of system or plant, which can be achieved by developing co-generation or polygeneration systems. Co-generation and polygeneration systems for electricity production, heating, cooling and desalination powered by solar energy are widely investigated by researchers [18,19]. In terms of MD system integration with other thermal cycles, Liu and Martin [20] analyzed different possibilities to integrate membrane distillation with heat recovery chiller and gas engines for production of cooling, power and water for chip manufacturing unit. Kullab [21] experimentally and numerically analyzed the performance of air gap membrane distillation system developed my SCARAB development AB for utilization in cogeneration power plants. Khan et al. [22], performed economic analysis of a small scale biogas polygeneration plant integrating AGMD providing fresh water for village households in Bangladesh. The techno-economic viability of renewable hybrid energy and integrated MD (pv-battery-MD) system further optimized for a case study in rural Bangladesh [23]. Mohan et al. [24] investigated the possibility of integrating MD and absorption chiller with a traditional combined cycle power plant. Both the chiller and MD are completely driven by waste heat recovered from the power plant, leading to an impressive payback period of 1.4 years and net cumulative savings of $\$ 66$ Million. Further, the solar driven polygeneration system integrated with membrane distillation unit is dynamically simulated and experimentally validated by Mohan et al. [25]. The solar thermal polygeneration system for simultaneous production of cooling through absorption chiller, clean water using MD and domestic hot water was designed and tested for weather conditions of UAE [26]. 
Literature studies prove benefit of integrated system development; however studies focused upon large scale or industrial applications.

The present work is extension of our previous study on sustainable integration of single cassette MD water purifier into solar hot water system that can produce $1.5-3 \mathrm{~kg} / \mathrm{h}$ of pure distillate along with domestic hot water production for a single family dwelling of five in the region $[27,28]$. Solar thermal heating systems are very much common nowadays for fulfilling different domestic and commercial needs. Solar water heating is one of the most popular solar thermal systems and accounts for $80 \%$ of the solar thermal market worldwide [29]. In dry and arid regions like UAE, lack of fresh water resources corresponds to high solar insolation. Theoretically, the average solar insolation in the region of around $600 \mathrm{~W} / \mathrm{m}^{2} \mathrm{~h}$ is sufficient to run solar domestic hot water (SDHW) systems at more than 95\% solar fractions. In UAE, hot water is needed during the months from September to May and since the water gets heated to 35 to $45^{\circ} \mathrm{C}$ in the mains during sunny months, solar thermal systems would be less efficient in summer [30]. A brief research on the design approach of UAE-based suppliers of solar heaters reveals the fact that the majority of SDHW systems $(60 \%)$ are designed for solar fractions less than $75 \%$ [31]. In recent years, the residential building council in UAE promoting utilization of SDHW heaters to regulate energy consumptions and also adapting sustainable strategies for conserving drinkable water for residential population. The proposed solar co-production system could maximize the overall solar fraction through co-production of heat and pure water utilizing available energy effectively. Thus, the overall thermal performance of the system could be increased and, additionally, it could act as source for potable water production.

A similar study has been conducted by us in UAE using multi cassette MD modules to analyze the performance of co-generation of pure water and heat using different integration strategies [32]. Novelty of present work is integration of a single cassette module for co-generation in a realistic application of DHW withdrawal especially direct solar combi MD configuration. In this approach, heat is directly used for DHW production after supplying MD module and heat from MD return line is not recovered. The multi cassette MD module system does not address real application of hot water generated and uses an external heat exchanger for recovering heat from MD module. This research paper provides detailed experimental campaign conducted on individual operation of SDHW, single cassette SMD systems and their integrated operation in two different configurations; solar thermal store integrated MD (STSMD) and direct solar combined MD (SCMD) for co-production of pure water and heat.

\section{Pilot Plant Development}

A bench-scale experimental setup was first developed for membrane characterization studies, parameter identification and model development. Details of the bench scale experiments were discussed in our previous publications $[27,28]$. Controlled experiments were conducted on MD system to determine the individual uncertainties of temperature, flow rate and distillate weight measurements. Table 1 shows the list the various parameters measured, operational range and accuracy of the sensors used for measurements. Sensors are located at inlet and outlet lines of the MD module as shown on Figure 1. Experiments were conducted for $3 \mathrm{~h}$ with a data acquisition interval of $10 \mathrm{~s}$ and total collected data were used to estimate uncertainty. The uncertainty in actual temperature measurements was estimated to be $\pm 0.2{ }^{\circ} \mathrm{C}$ for the sensors used with a standard deviation of $0.05{ }^{\circ} \mathrm{C}$. Considering the MD flow rate measurements, the standard deviation was less than $0.3 \mathrm{~L} / \mathrm{h}$, measured flow difference from the set point was less than $\pm 1.5 \mathrm{~L} / \mathrm{h}$. An overall uncertainty of approximately $\pm 10 \mathrm{~g} / \mathrm{h}$ was determined for weight measurement of the distillate collected.

In order to realize performance dynamics of co-generation of pure water and hot water, a pilot test facility has been designed and installed at RAKRIC, UAE. A regular solar domestic hot water system was procured and installed with increased energy source capacity as shown Figure 1.

The pilot plant has been designed to have the flexibility of experimenting at higher hot water and pure water demands relative to standard demand profile of single family household. The experimental 
rig consists of eight flat plate solar thermal collectors (FPC installed at tilt $35^{\circ}$ ) from Tisun, Austria and three Evacuated tubular collectors (ETC installed at tilt $15^{\circ}$ ) from Sunda Solar, China. Different arrays were designed and connected in series/parallel combinations in order to operate with varying collector areas. Solar thermal energy is charged either to a stratified storage tank of $520 \mathrm{~L}$ capacity or to a $300 \mathrm{~L}$ normal mixing storage tank. Thermal store was charged during sunshine hours and utilized for DHW with drawl throughout the day according to desired profile.

Table 1. Measured parameters, operational range and accuracy of instruments.

\begin{tabular}{cccc}
\hline Measured Parameters & Type, Range & Operational Range & Accuracy \\
\hline MD Hot in T & $\mathrm{Pt}-100,0-200{ }^{\circ} \mathrm{C}$ & $40-90{ }^{\circ} \mathrm{C}$ & $\pm 0.1^{\circ} \mathrm{C}$ \\
MD Cold in T & $\mathrm{Pt}-100,0-200{ }^{\circ} \mathrm{C}$ & $10-50{ }^{\circ} \mathrm{C}$ & $\pm 0.1^{\circ} \mathrm{C}$ \\
Feed Conductivity & $0-20,000 \mu \mathrm{S} / \mathrm{cm}$ & $1000-15,000 \mu \mathrm{S} / \mathrm{cm}$ & $\pm 1 \mu \mathrm{S} / \mathrm{cm}$ \\
Distillate Conductivity & $0-50 \mu \mathrm{S} / \mathrm{cm}$ & $0-30 \mu \mathrm{S} / \mathrm{cm}$ & $\pm 0.1 \mu \mathrm{S} / \mathrm{cm}$ \\
MD Flow & $0-200 \mathrm{~L} / \mathrm{min}$ & $1-10 \mathrm{~L} / \mathrm{min}$ & $\pm 0.1 \mathrm{~L} / \mathrm{min}$ \\
Distillate mass & $0-50 \mathrm{~kg}$ & $0-30 \mathrm{~kg}$ & $\pm 0.05 \mathrm{~g}$ \\
\hline
\end{tabular}

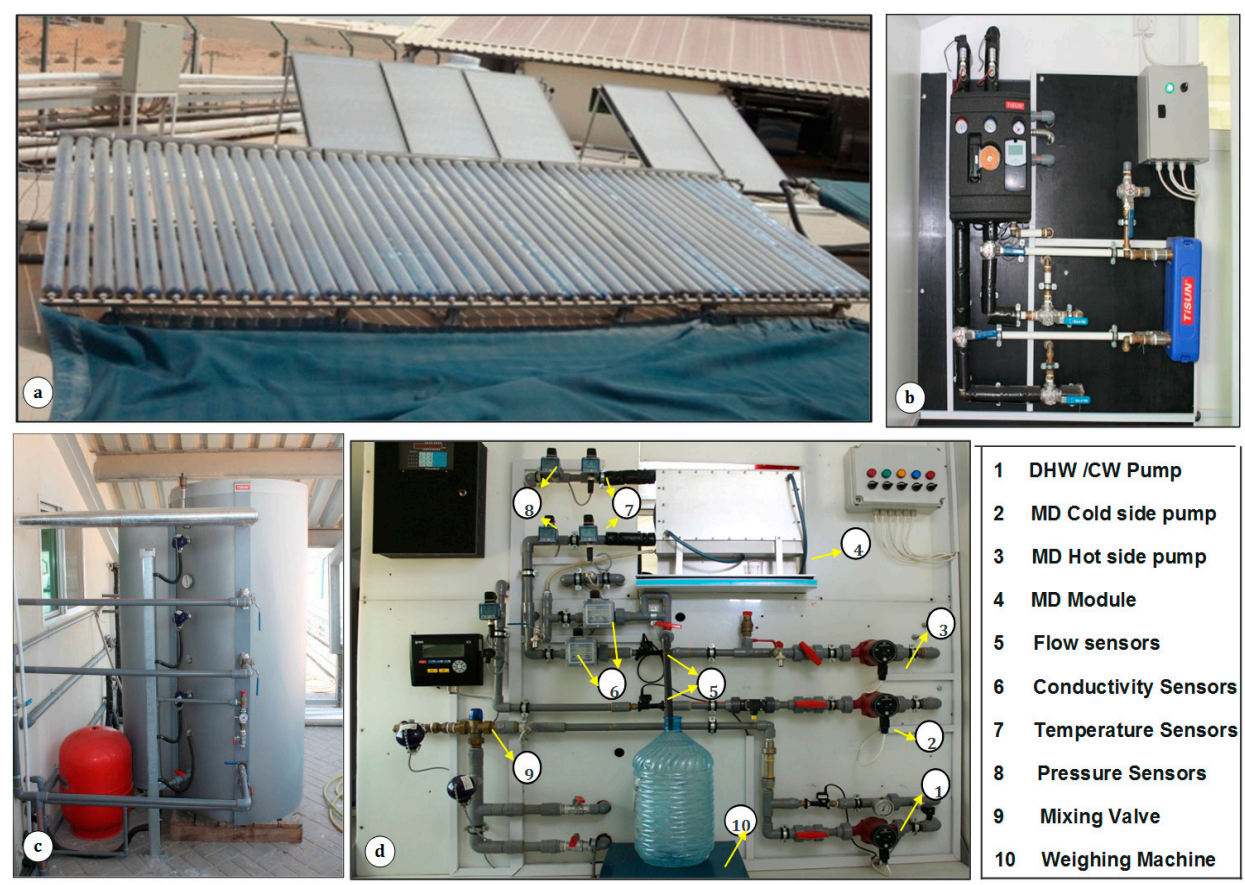

Figure 1. Pilot system installed at UAE: (a) flat plate and evacuated solar thermal collector arrays; (b) solar station circuit; (c) stratified thermal storage tank; and (d) MD module along with all instrumentation.

The AGMD module consists of a gap of $2.4 \mathrm{~cm}$ between two aluminum condensing plates, behind which are located the cooling channels in a serpentine shape covered with rigid aluminum end plates. Two hydrophobic poly tetra fluoro ethylene (PTFE) membranes each having a surface are of $0.1 \mathrm{~m}^{2}$ (total area $0.2 \mathrm{~m}^{2}$ ) are thermally welded on to a polypropylene cassette frame to fit into the module. Thickness and pore size of the membranes are $280 \mu \mathrm{m}$ and $0.2 \mu \mathrm{m}$ respectively. Membrane distillation system was integrated in a flexible manner to operate with heat energy from the thermal storage tank and from direct solar hot water circulation circuit through a stainless steel plate heat exchanger. All circuits in the test facility were equipped with different measurement and control devices to monitor and control the process. Details of the experimental system were presented in our previous publication [28]. 


\section{Modes of Operation, Integration and Dynamic Simulation}

\subsection{Experimental Systems}

The experimental pilot system was operated in various modes through different component integrations for both individual system performance analysis and co-production performance analysis. Figure 2 shows the schematic circuit of regular solar domestic hot water (SDHW) system having a thermal storage tank of $300 \mathrm{~L}$ and three flat plate collectors. Cold water was supplied from a large storage tank which gets heated up in thermal store subsequently delivered to a mixing valve for DHW preparation at around $50-55{ }^{\circ} \mathrm{C}$.

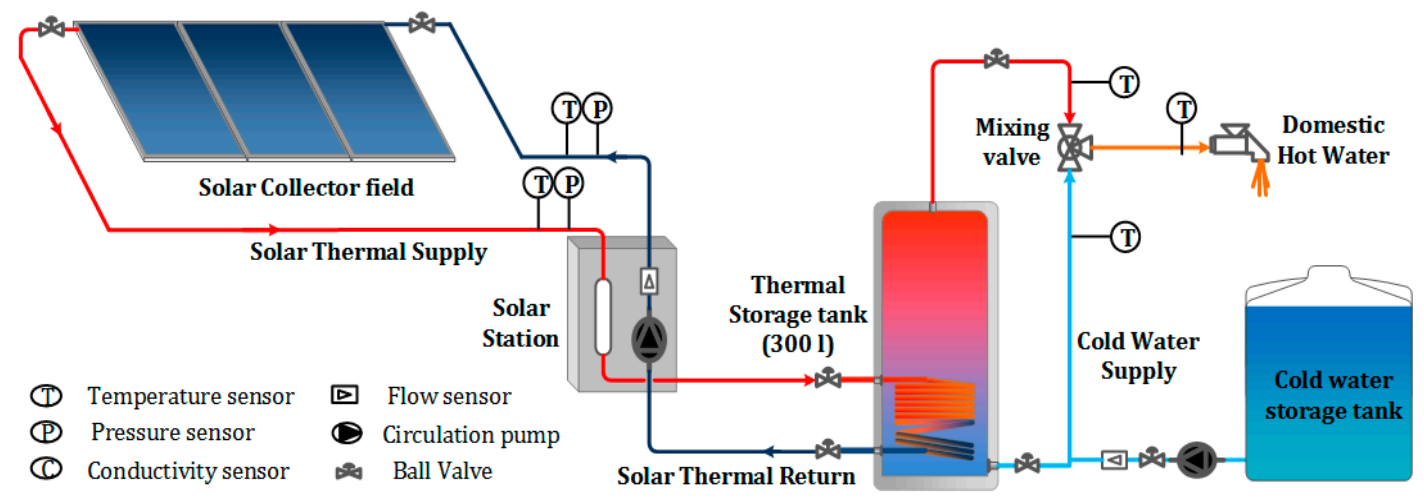

Figure 2. Schematic showing individual operation of solar domestic hot water (SDHW).

Stand alone solar membrane distillation (SMD) mode of operation, as shown Figure 3, consists of a heat exchanger and small buffer tank for MD feed water. AGMD system could be operated for only pure water production using three or five flat plate collectors by shutting off tank integration lines. This is one of the common modes of operation used by various researchers for solar membrane distillation applications. Some researchers also analyzed solar MD performance through thermal store integration for $24 \mathrm{~h}$ operation of MD for pure water production [33].

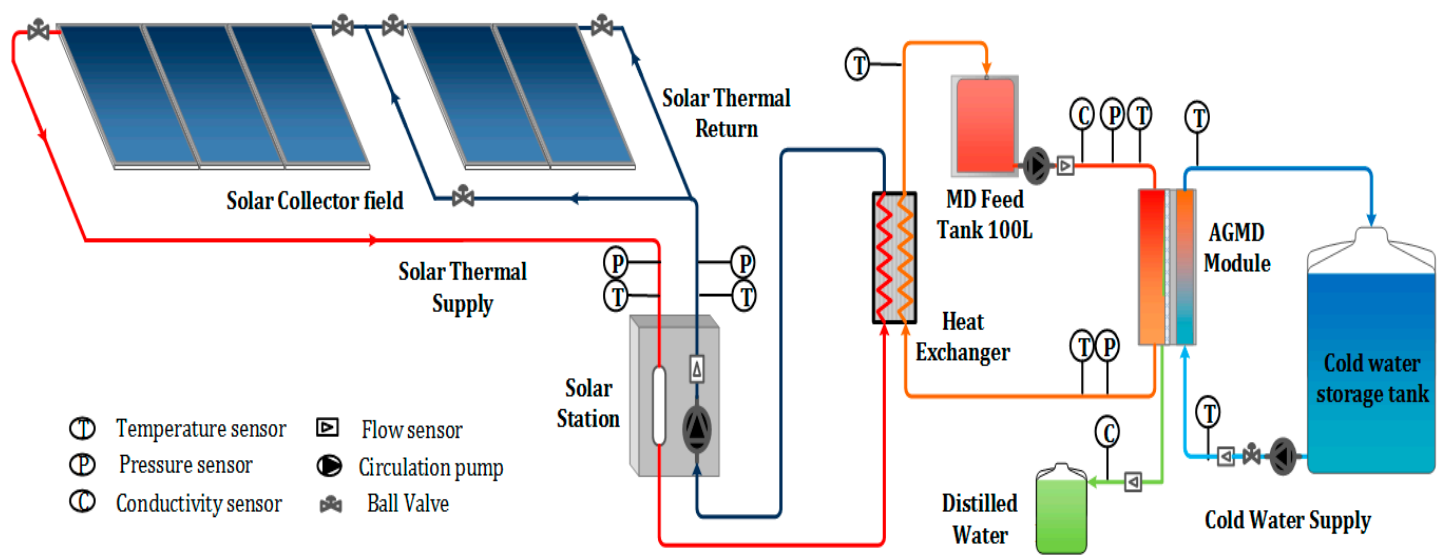

Figure 3. Schematic showing individual operation of solar membrane distillation (SMD).

As shown in Figure 4, solar thermal store integrated MD (STSMD) mode of operation involves integration of AGMD module to thermal storage tank that purifies the storage medium, i.e., municipal tap/brackish water filled in the tank. Hot water at higher temperature zone of storage tank is pumped into MD unit and returned back to lower temperature zone. Compared to direct solar configuration explained below, this mode of integration should reduce overall system cost by eliminating components 
such as heat exchanger and separate buffer storage for MD feed. Through this integration, reasonable assumption has been made that the issue of low recovery ratio for AGMD modules compared to conventional reverse osmosis ( $\mathrm{RO})$ systems could be ignored [13]. This statement attributes to the batch operation of MD system instead of continuous processes such as reverse osmosis (RO), in which $50 \%-60 \%$ could be recovered and the rest drained as brine. MD outlet stream returns back to storage tank and virtually there is no draining. However after few cycles of filling and MD operation (few months), thermal storage tank has to be drained and filled with new batch to avoid scaling. Therefore, for tank integration, MD outlet water after purification returns to the tank and the percentage of loss would not have much effect on temperatures of the large thermal buffer. From a large tank (as in the case of STSMD) of $500 \mathrm{~L}$ volume, $20 \mathrm{~L}$ of water is withdrawn as pure distillate by MD which is $4 \%$ of total volume. This lost volume is filled at the end of the day but fluctuations are minimal.

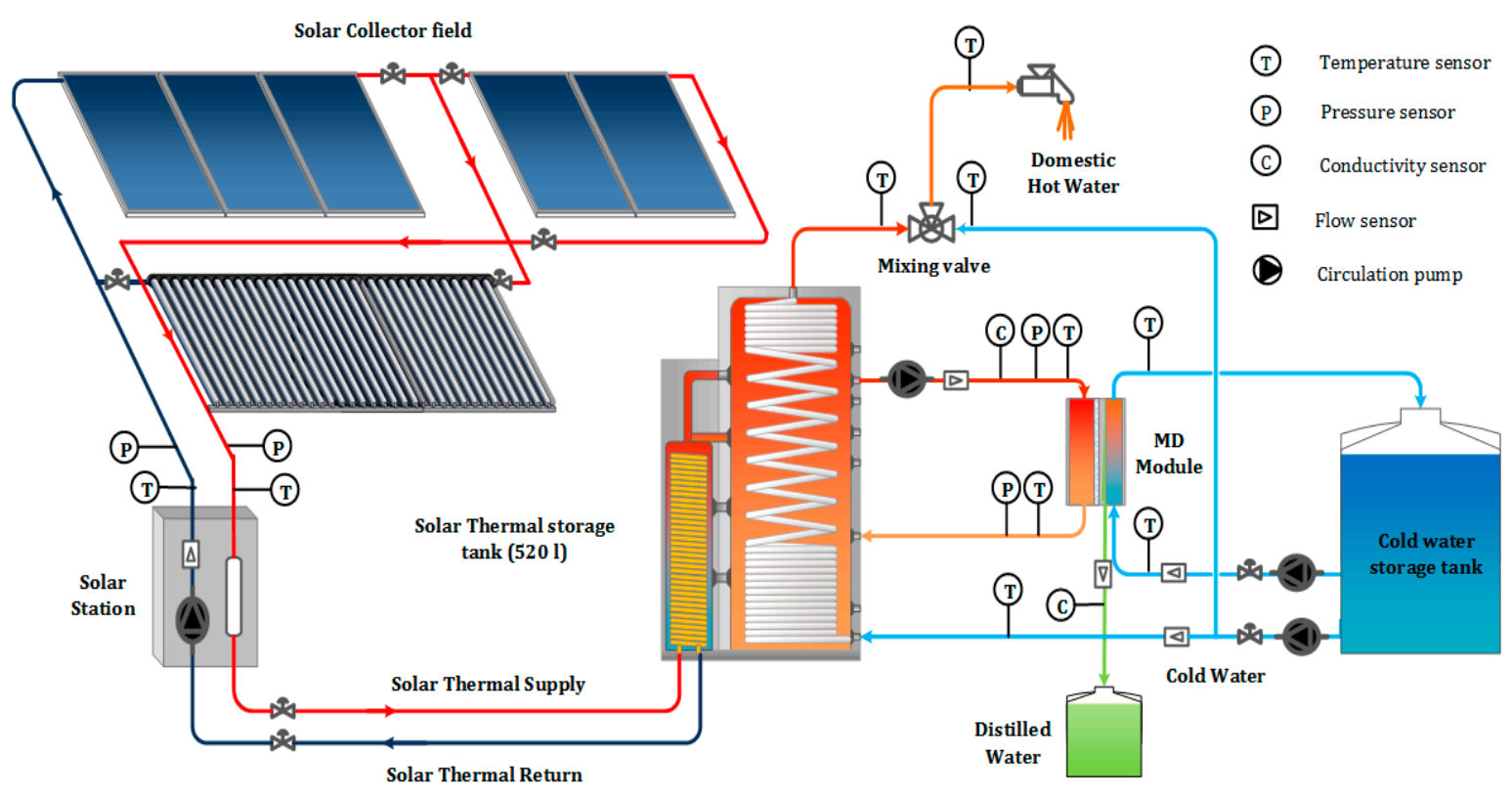

Figure 4. Schematic representation of thermal store integrated MD (STSMD).

However, after initial phase of experimentation on STSMD mode, AGMD module used in the study found to be very sensible to pressure fluctuations on feed inlet circuit from thermal storage tank, and hence MD loop has been separated from thermal energy storage (TES) and installed in solar thermal collector loop for direct energy gain for solar collectors shown in Figure 5. A stainless steel heat exchanger was installed in solar circuit to heat up MD feed stream circulated via a small buffer storage tank of $100 \mathrm{~L}$ capacity. Therefore, this batch mode of operation was termed as direct solar combi MD (SCMD) which involves direct solar energy supply to MD feed through heat exchanger and then the return hot water from exchanger is diverted to charge thermal storage tank for DWH preparation instead of returning back to solar collector loop. The series disbursement of energy in solar combi MD enables efficient use of energy according to the requirements of MD and DHW. In SMD or SCMD system, a small thermal buffer decreases by $20 \%$ at the end of the day. Filling cold water into this at the end of the day would decrease total temperature of the tank thus takes some time for initial heating the following day. SCMD system has been operated with varying collector areas and storage volume for DHW. 


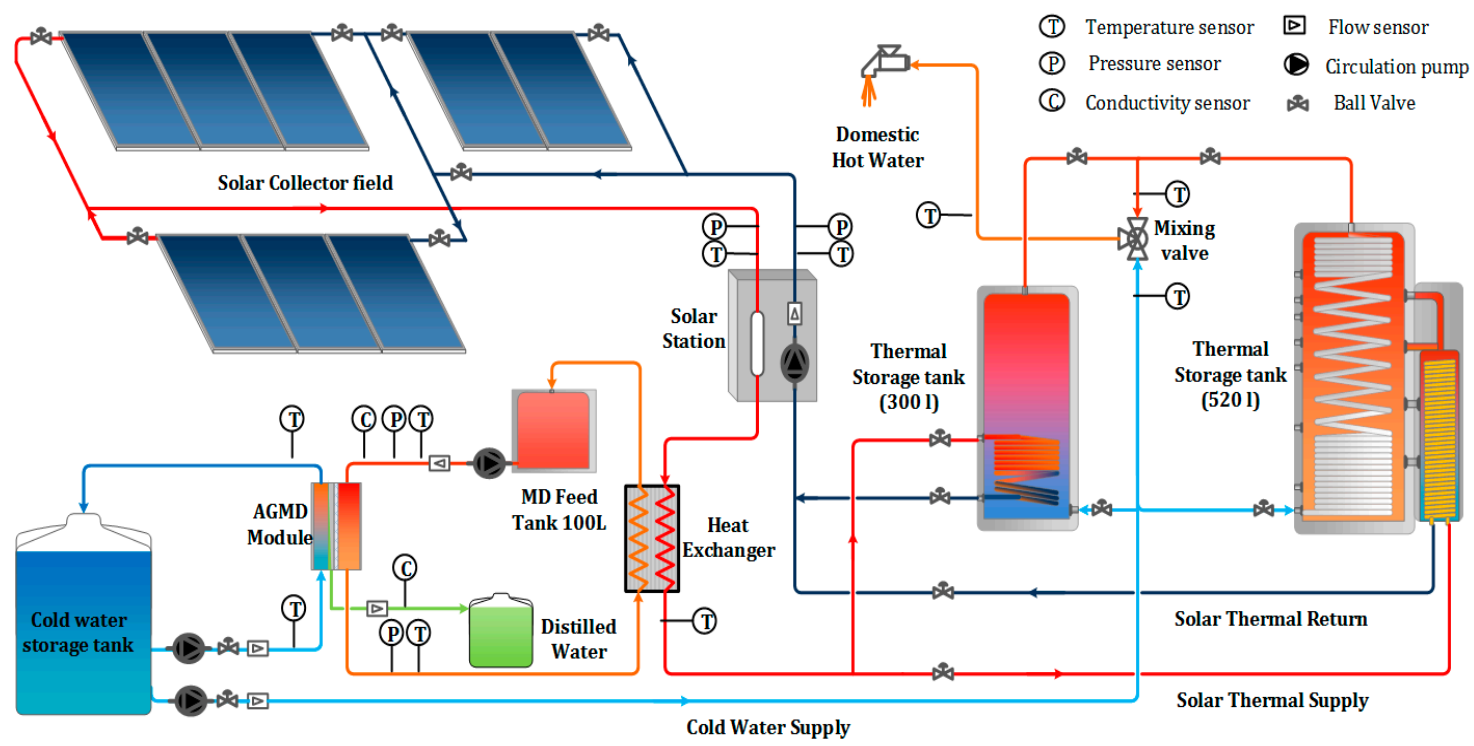

Figure 5. Schematic representation of direct solar combi MD system (SCMD).

\subsection{Dynamic Simulation of Individual and Combined Systems}

The performance of individual and combined systems has been dynamically simulated using TRNSYS tool. The basic components, known as types in TRNSYS library, have been chosen for assembly, as shown in Figure 6. According to the experimental system specifications, components like solar collectors, storage tanks, pumps, controllers, heat exchangers, have been designed. AGMD system is modeled using laboratory experimental data and model equations have been included in TRNSYS to analyze both the energy and mass fluxes within the modules, based on inlet hot and cold water temperatures. Data obtained from simulation has been processed further to determine combined solar fraction for co-generation system as well as auxiliary heating demand requirement for MD operation. One of our previous studies provides more details about simulation equations and types of components used in TRNSYS [17].

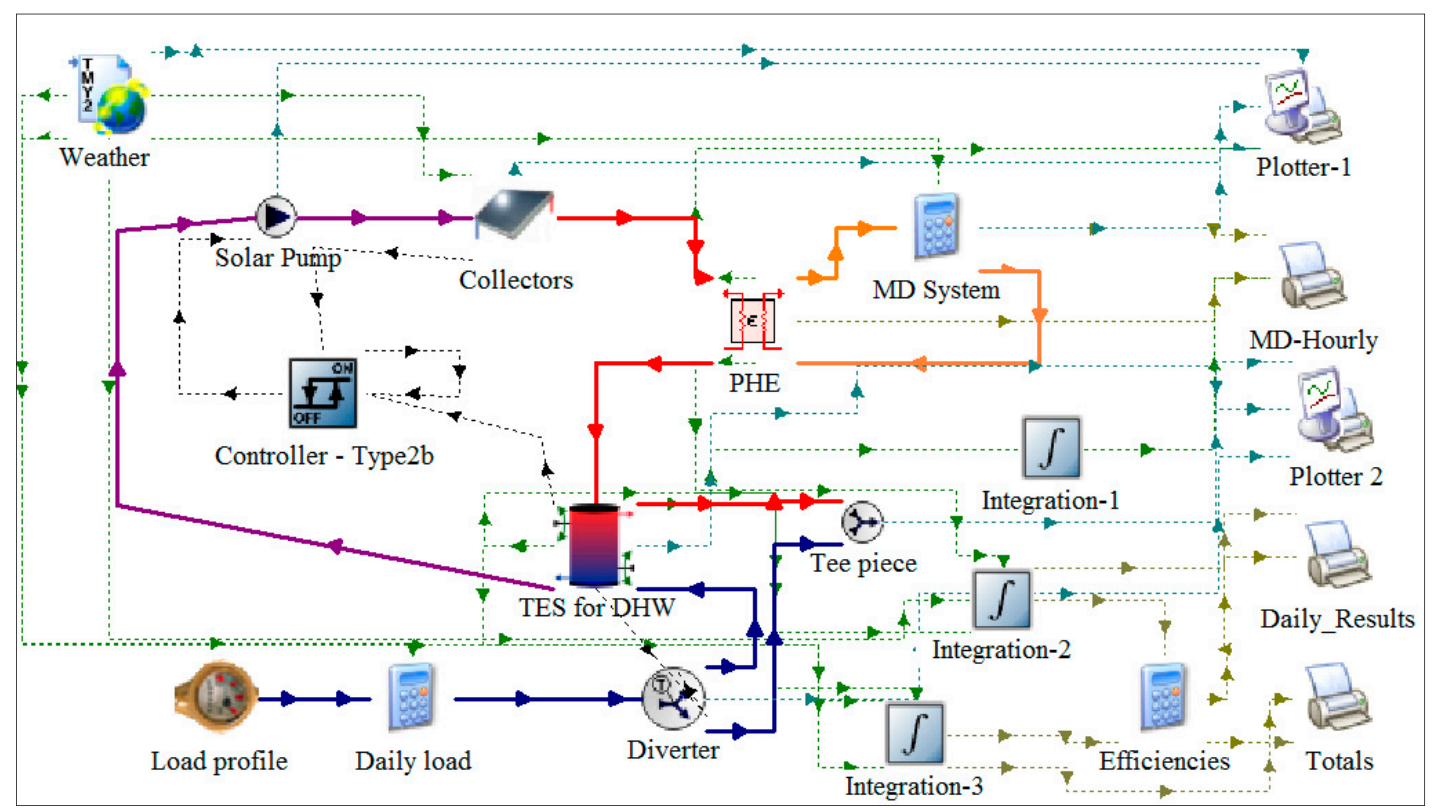

Figure 6. System assembly diagram of SCMD system in TRNSYS simulation studio. 


\section{Results and Discussion}

Field experimental campaign has been carried for five months on various modes mentioned in earlier section. The main objective of experimentation was to analyze co-generation system dynamics and energy distribution profiles between MD and DHW demands for the present application of fulfilling pure water and hot water demand of a single family of five members in UAE region. Table 2 summarizes various operational conditions maintained or varied for experimental analysis on co-generation of pure water and hot water.

Table 2. Operational conditions used for testing co-generation system.

\begin{tabular}{|c|c|c|c|}
\hline Operational Parameter & Specification & Units & Notes \\
\hline MD Hot feed flow rate & $6-7$ & $\mathrm{~L} / \mathrm{min}$ & $\begin{array}{l}\text { Obtained from the lab scale } \\
\text { experimental data }\end{array}$ \\
\hline MD feed water conductivities & 1000 to 15,000 & $\mu \mathrm{S} / \mathrm{cm}$ & Diluted sea water to brackish \\
\hline MD Feed storage volume & $50-100$ & $\mathrm{~L}$ & $\begin{array}{l}\text { Volume changed to compare MD } \\
\text { performance variation }\end{array}$ \\
\hline MD operational hours & 7-9 & h/day & $\begin{array}{l}\text { Depends on TES temperatures for } \\
\text { STSMD and initial charging of feed } \\
\text { storage tank for SCMD }\end{array}$ \\
\hline Flat plate collector area (FPC) & $7.65,12.75$, and 20.4 & $\mathrm{~m}^{2}$ & $\begin{array}{l}\text { Minimum area required for } \\
\text { co-generation would be analyzed }\end{array}$ \\
\hline Evacuate Tube collector area (ETC) & 12 & $\mathrm{~m}^{2}$ & Compared with FPC operation \\
\hline Thermal storage tank volume & $\begin{array}{c}520 \text { (stratified), } \\
300 \text { (normal mixing) }\end{array}$ & $\mathrm{L}$ & $\begin{array}{l}\text { Effect of reduced volume on } \\
\text { distillate production }\end{array}$ \\
\hline \multirow{2}{*}{ Domestic hot water flow } & 250 & L/day & $50 \mathrm{~L} /$ person/day \\
\hline & 500 & $\mathrm{~L} /$ day & $\begin{array}{l}100 \mathrm{~L} / \text { person/day } \\
\text { solar rating and certification }\end{array}$ \\
\hline Domestic hot water temperature & $50-55$ & ${ }^{\circ} \mathrm{C}$ & $\begin{array}{l}\text { corporation (SRCC) } 24 \mathrm{~h} \\
\text { withdrawal profiles }\end{array}$ \\
\hline Solar circuit operational hours & $7-9$ & h/day & During summer months \\
\hline & $6-7$ & & During winter months \\
\hline
\end{tabular}

MD feed conductivities has been varied from 1000 to $15,000 \mu \mathrm{S} / \mathrm{cm}$ and distillate conductivities of less than $10 \mu \mathrm{S} / \mathrm{cm}$ were observed in all experimental campaign. Hot inlet temperatures for MD at around $60-80^{\circ} \mathrm{C}$ would eliminate possibility of microbial contaminants in the distillate. A detailed analysis of the distillate obtained using present MD cassette has been reported by fellow researchers in another study [34], and hence not evaluated in present study. However, in order to qualify the water to be suitable for further processing to make drinkable water, post mineralization and treatment options have to be considered, which is not in the scope of present work. Following sections provide operational performances of individual and co-generation systems.

\subsection{Solar Domestic Hot Water System (SDHW)}

Operational dynamics of a standard solar hot water system has been analyzed first before developing an integrated system. Literature study indicates that two efficient flat plate collectors could easily fulfill DHW demand due to availability of high insulation in UAE. However, most of the systems would be designed for $70 \%$ solar fraction, practically more than $90 \%$ SFDHW could be achieved. Figure 7 shows the temperature profile of storage tank of $300 \mathrm{~L}$ capacity charged with three flat plate collectors configuration. On average, 50\% collector efficiencies was achieved during the test day in July (peak summer) for a standard DHW withdrawal profile according to SRCC. Due a high withdrawal volume in morning hours, tank temperature decreases and increases when solar charging begins, as shown in Figure 7, and therefore initial hours of operation are critical for co-production system. 


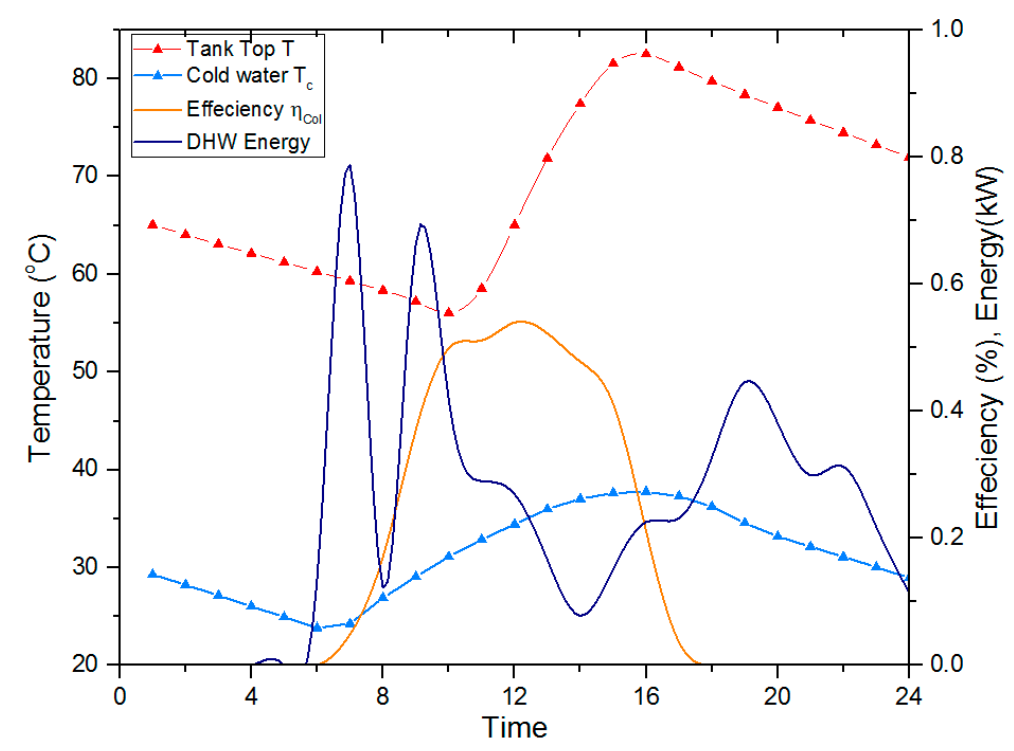

Figure 7. Dynamics of solar hot water system (SDHW).

\subsection{Solar Driven Membrane Distillation (SMD)}

After SDHW analysis, it is important to understand performance of standalone MD system which could be operated in two modes either with thermal store integration or with direct solar integration. For the typical production of $20 \mathrm{~L} /$ day using the existing modules, large thermal store is not needed due to the advantage of higher MD inlet temperatures using direct solar energy. However, a small feed buffer tank is used to operate system in batch mode because of low recovery ratio of AGMD modules [13]. Figure 8 shows the behavior of SMD system during summer and winter days. It is evident that average delta $\mathrm{T}\left(\mathrm{T}_{\text {MDhotin }}-\mathrm{T}_{\text {MDcoldin }}\right)$ of $50{ }^{\circ} \mathrm{C}$ could be achieved in both cases which is the main driving force for the process. In both cases desired pure water demand of $20 \mathrm{~L} /$ day has been fulfilled using a 4 FPC configuration with peak distillate flow of $3 \mathrm{~kg} / \mathrm{h}$ during noon. Similar to SDHW system, collector efficiency of 50\% was achieved in summer, whereas, in winter, $60 \%$ efficiency is achieved which attributes to the high collector tilt angle $\left(35^{\circ}\right)$ maximizing energy gain in winter months.

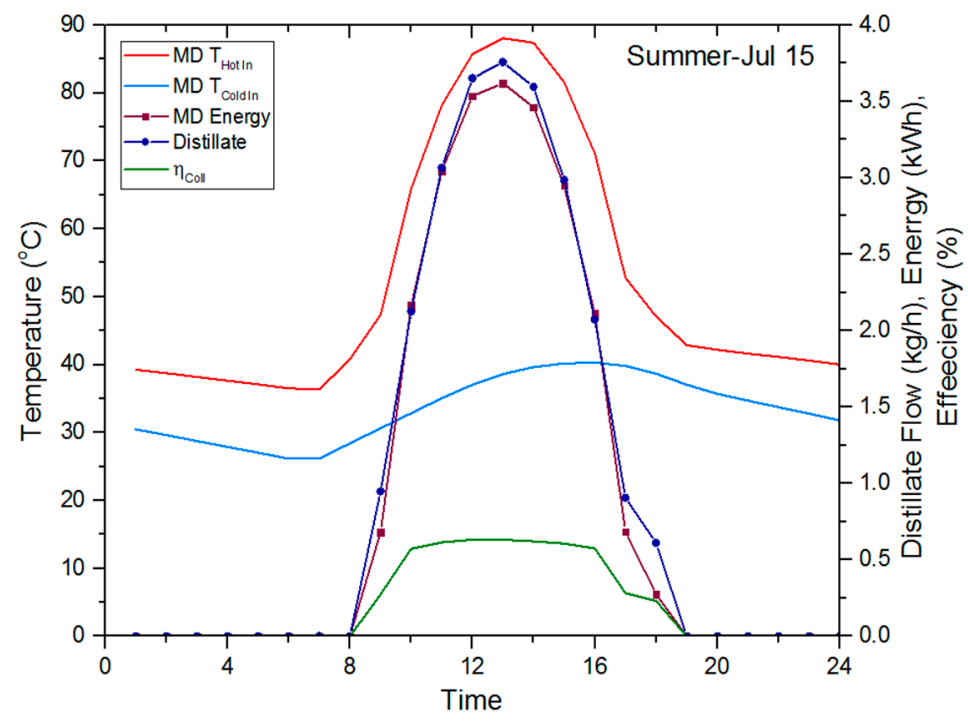

Figure 8. Cont. 


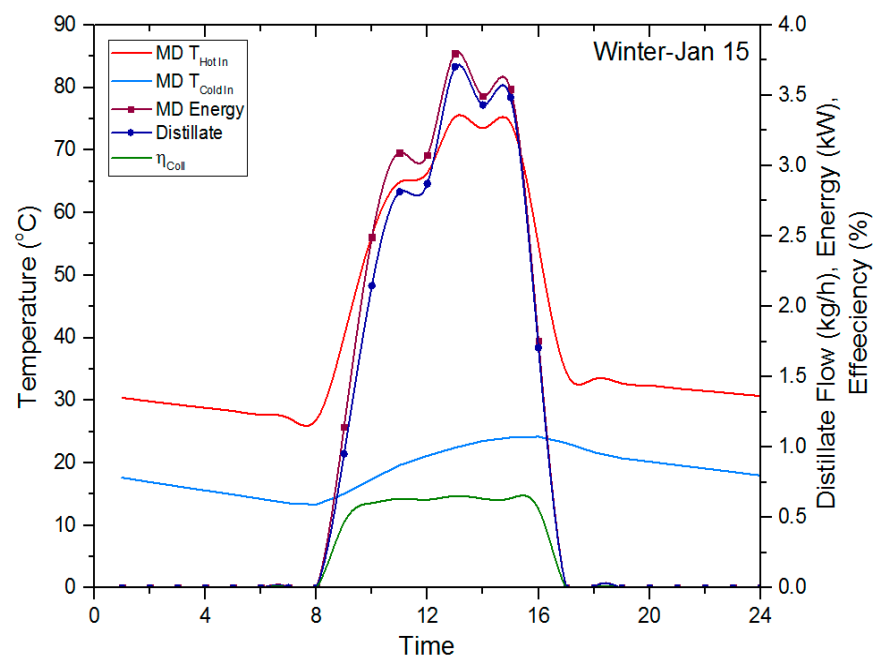

Figure 8. Summer and winter operation of Solar Membrane Distillation (SMD).

\subsection{Thermal Store Integrated Co-Production}

Field experiments were performed for 2 months (July, August) to analyze the performance of solar co-production system. Typical dynamic behavior of MD module integrated with thermal storage tank is shown in Figure 9. Experiment was carried in a peak summer day of UAE with 5 FPC configuration and a cumulative distillate production of $18 \mathrm{~L}$ was obtained within $8.75 \mathrm{~h}$ of operation. The average water production corresponding to collector area is $1.52 \mathrm{~kg} / \mathrm{m}^{2}$. An advantage of thermal store integration is startup time for MD since it is directly connected to storage which was charged sufficiently on the day before so that MD process could be initiated along with solar charging. However, it is evident from the plot that distillate flow decreased during early hours of operation. This trend is due to demand for both DHW and MD at initial stage of solar charging. MD flow rate increased to a peak flow of $2.5 \mathrm{~kg} / \mathrm{h}$ at 14:00 $\mathrm{h}$ and decreased drastically towards the evening. Municipal tap/brackish water in the thermal storage having a conductivity of $1600 \mu \mathrm{S} / \mathrm{cm}$ is purified to pure distillate with conductivities less than $0.5 \mu \mathrm{S} / \mathrm{cm}$. It is also worth noting slight increase in cold inlet temperatures due to continuous addition of heat in cold water storage tank by cold outlet stream from MD unit. Cold water temperatures in $3 \mathrm{~m}^{3}$ cold storage tank increased by $3{ }^{\circ} \mathrm{C}$ during the day which might be helpful in reducing DHW energy consumption during night withdrawal.

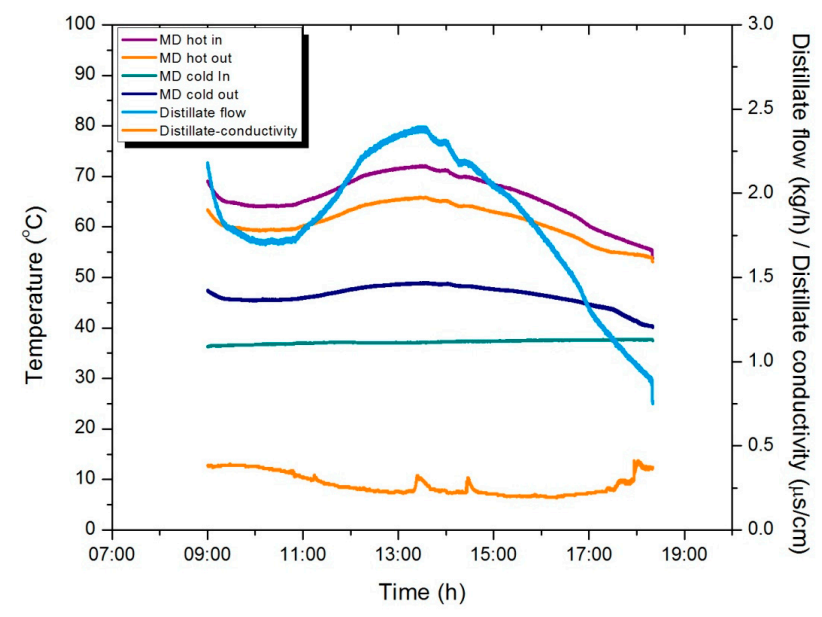

Figure 9. AGMD dynamic behavior during experiments on peak summer day. 
Operational profile integrated STSMD system is shown in Figure 10 which provides energy distribution between DHW and distillation using MD. Storage tank temperature plays an important role in direct integrated system. Since, stratified tank was used in our system, temperatures between 60 and $70{ }^{\circ} \mathrm{C}$ could be maintained in layer of MD hot water supply. The required DHW of $250 \mathrm{~L}$ was withdrawn manually during initial two hours and then after noon with average temperature of $50{ }^{\circ} \mathrm{C}$. From the total useful energy gain, $62 \%$ of energy is utilized by MD and $17 \%$ for DHW production and the remaining being system losses.

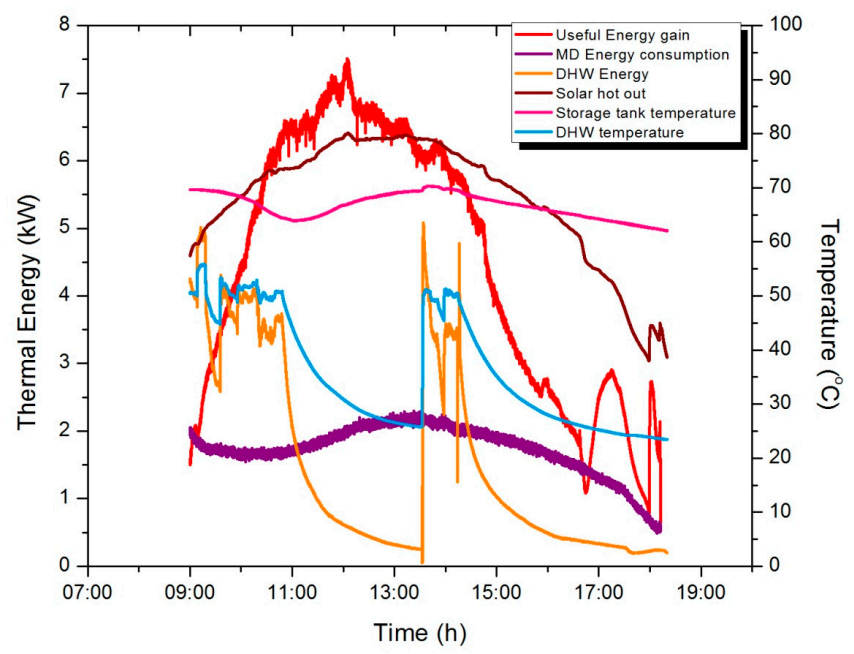

Figure 10. Typical daily operational profile of solar field and energy distribution of STSMD.

As mention in earlier section, individual uncertainties for MD temperature and flow rates were obtained through bench scale experimentation. Controlled experiments were also performed to determine the uncertainties in temperature, flow measurement in solar and DHW loops. Average uncertainty of $0.5^{\circ} \mathrm{C}$ was assumed for temperature measurements due to the external location of sensors and fluctuations in DHW cold inlet temperatures. As shown in Table 3, DHW, solar flows have an uncertainty of $0.1 \mathrm{~L} / \mathrm{min}$ for the operational conditions studied in the experiments. To estimate the overall uncertainty for the thermal energy gain/consumption, the individual uncertainties of the respective sensor values are considered as stated above. The Gaussian law of error propagation Equation (1) was used to estimate the combined standard uncertainty based on individual uncertainties.

$$
u_{c}(y)=\sqrt{\sum\left(\frac{\partial y}{\partial X_{i}} u\left(x_{i}\right)\right)^{2}}
$$

where $u_{c}(y)=$ combined standard uncertainty of the output quantity and $u\left(x_{i}\right)=$ standard uncertainties of input quantities. Table 4 shows the expanded uncertainty of useful energy gain, MD and DHW energy consumption for the experimental data shown in Figure 10. The reported uncertainty is based on a standard uncertainty multiplied by a coverage factor $k=2$, providing a level of confidence of approximately $95 \%$.

Table 3. Uncertainty of individual parameters.

\begin{tabular}{cc}
\hline Measured Parameters & Average Uncertainty \\
\hline MD Hot inlet and outlet T & $\pm 0.2^{\circ} \mathrm{C}$ \\
Solar inlet and outlet T & $\pm 0.5^{\circ} \mathrm{C}$ \\
DHW Cold in T, DHW T & $\pm 0.5^{\circ} \mathrm{C}$ \\
MD Flow & $\pm 0.025 \mathrm{~L} / \mathrm{min}$ \\
DHW Flow, Solar Flow & $\pm 0.1 \mathrm{~L} / \mathrm{min}$ \\
\hline
\end{tabular}


Table 4. Expanded uncertainty estimation.

\begin{tabular}{ccc}
\hline Estimated Parameter & Function & Expanded Uncertainty \\
\hline Useful Energy Gain & $f\left(S_{\text {Tin }}, S_{\text {Tout }}, S_{F}\right)$ & $4.48 \pm 0.484 \mathrm{~kW}$ \\
DHW Energy consumption & $f\left(D H T_{T}, D H W_{\text {Cin }}, D H W_{F}\right)$ & $1.537 \pm 0.317 \mathrm{~kW}$ \\
MD Energy consumption & $f\left(M D_{\text {HinT }}, M D_{\text {HoutT }}, M D_{F}\right)$ & $1.727 \pm 0.2 \mathrm{~kW}$ \\
\hline
\end{tabular}

Tests have been performed on three consecutive days of July in order to analyze STSMD performance with changing collector area. From Figure 11, it is obvious that the driving force delta T between MD hot and cold sides decreases with decrease in energy source capacity. It is also evident that cumulative production decreased half from 5 FPC to 3 FPC operations. Evacuated tubular collectors with absorber area of $8.58 \mathrm{~m}^{2}$ were able to produce $14 \mathrm{~L}$ a day. Steep decrease of delta $\mathrm{T}$ was observed for flat plate collectors during initial hours whereas for tubular collectors regular rise of delta $\mathrm{T}$ was observed. This is because of rapid charging of storage tank using ETC due to high collector outlet temperatures.

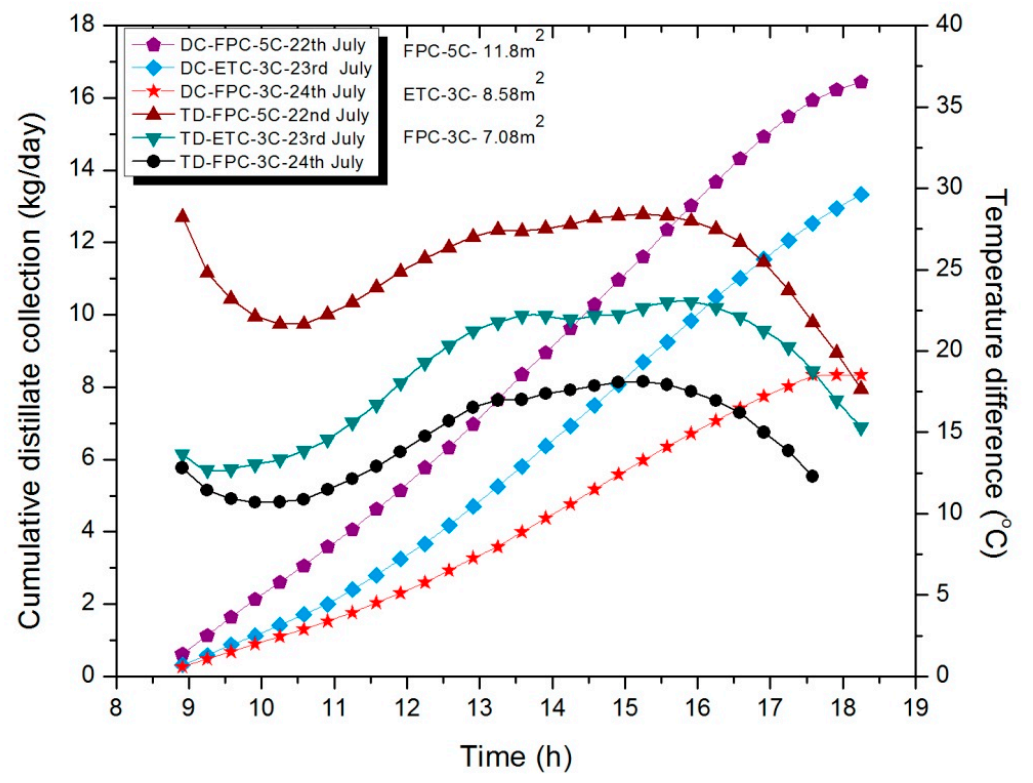

Figure 11. Cumulative daily distillate profile and MD driving force with different collector area.

One advantage of thermal store integration would be operation of MD for extended hours beyond solar hours. Even though direct integration was feasible to operate at prescribed conditions, careful attention has to be given to pressure fluctuations during refilling of lost volume from thermal energy store. Since MD module was very sensitive to hot feed pressures, relief valves should be used in MD feed line to withstand pressure fluctuations. One more limitation in such integration would be the selection of TES. In STSMD configuration, thermal store with stratification was used in order to have stable temperatures in the layers from which hot water is supplied to MD. Stratified tanks are expensive compared to regular tanks without stratified thermal distribution. Therefore, for realistic applications, a normal mixing tank having internal thermal mixing of layers was used for direct solar integration. Therefore, for SCMD, thermal store with internal heat exchanging coil should be used to avoid mixing of DHW and treated water. Therefore, further research focus has been shifted to direct solar thermal supply using heat exchanger to a small feed tank for MD with the option of integrating with normal mixing tank. 


\subsection{Direct Solar Combined Co-Generation (SCMD)}

Due to the drawbacks of thermal store integration for practical applications, experiments were performed to analyze the performance of direct solar cogeneration system with different collector area, storage volume and domestic hot water withdrawal rate. Additional components like plate heat exchanger and small MD feed buffer storage tank were installed and series of experiments are conducted between 09:00 and 18:00 during the months of September and October. DHW was withdrawn for $24 \mathrm{~h}$ operation cycle instead of daytime withdrawal employed in previous STSMD mode. Brackish water with conductivities ranging from 5000 to $15,000 \mu \mathrm{S} / \mathrm{cm}$ was treated to obtain pure distillate of less than $10 \mu \mathrm{S} / \mathrm{cm}$ in spite of fluctuations in feed concentration. As mentioned by several researches that MD distillate flux would not have significant changes with lower feed concentrations [35]. However, flux differences could be observed at higher concentrated water, e.g., productivity decay around $14 \%$ with increasing salinity (from 1 to $35 \mathrm{~g} / \mathrm{L}$ ) [13].

\subsubsection{Operational Performance of SCMD}

Typical daily performance of solar collector field and membrane distillation system with five-collector array using SCMD mode is shown in Figure 12.

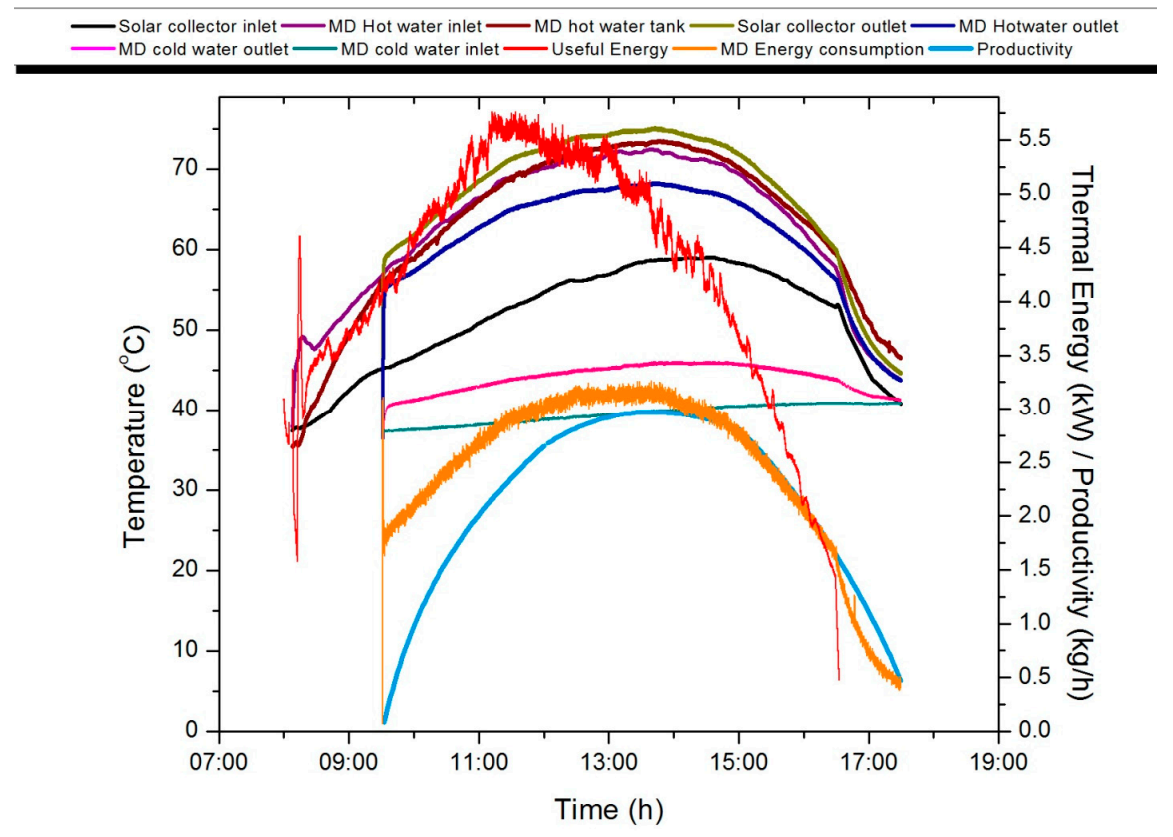

Figure 12. Typical daily operation profile of solar collector field and membrane distillation unit.

Flat plate collector circuit is operated from 08:00 to charge the 100 L MD thermal store. MD buffer thermal store is charged to $56{ }^{\circ} \mathrm{C}$ from initial temperature of $36{ }^{\circ} \mathrm{C}$ during $90 \mathrm{~min}$ charging period. During the test day, solar collector outlet temperature reaches a maximum of $75{ }^{\circ} \mathrm{C}$ and useful energy gained from collector field reaches of $5.6 \mathrm{~kW}$ around 12:00, whereas the total collector gain of $34 \mathrm{kWh}$ is achieved during the eight-hour operation. In terms of MD performance, $18 \mathrm{~kg} /$ day of potable water is produced during the test day and a maximum distillate flux of $3.1 \mathrm{~kg} / \mathrm{h}$ is achieved around 13:00, which is influenced by higher hot water supply temperature. Thermal energy requirement for the distillate during the final hour of operation is completely supported by $100 \mathrm{~L}$ MD thermal store, while performance of MD drops steeply as distillate productivity falls below $1 \mathrm{~kg} / \mathrm{h}$. In terms of energy consumption, $7.37 \mathrm{kWh}$ of thermal energy is consumed for $250 \mathrm{~L}$ of DHW preparation. Complete energy flows in solar cogeneration system is shown is Figure 13, overall system thermal efficiency of $50 \%$ is achieved with the system. 


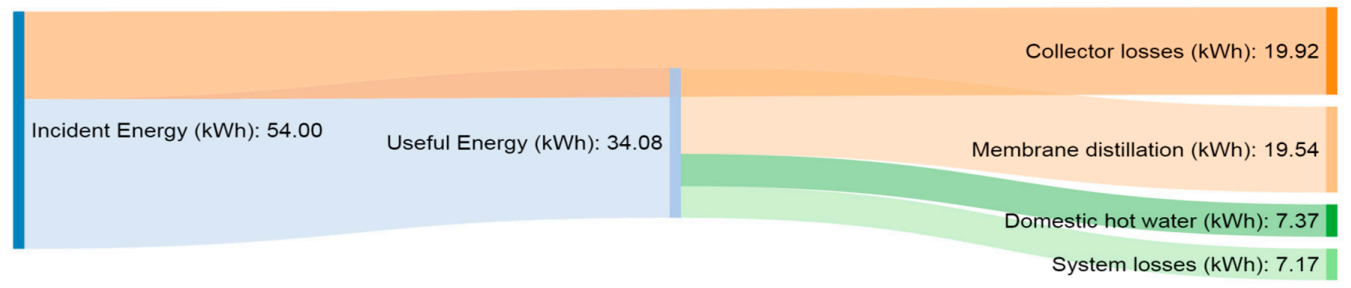

Figure 13. Energy flows in SCMD system.

Figure 14 presents 24-h operation profile of domestic hot water preparation according to SRCC withdrawal profile. During the beginning of the 24-h operation, tank top layer and bottom layer temperatures are maintained at $62{ }^{\circ} \mathrm{C}$ and $55^{\circ} \mathrm{C}$, respectively. Temperatures in the DHW tank are gradually decreased to $59^{\circ} \mathrm{C}$ and $50{ }^{\circ} \mathrm{C}$ before first hot water withdrawal. Top layer temperature dropped steeply to $56^{\circ} \mathrm{C}$ at 10:00 due to hourly hot water withdrawal. Charging of DHW thermal store begins with start the solar thermal circuit at 08:00 h. Both top layer and bottom layer raises close to $65^{\circ} \mathrm{C}$ at noon and then gradual declines in the temperature layers are caused due continuous withdrawal of domestic hot water, even after sunshine hours.

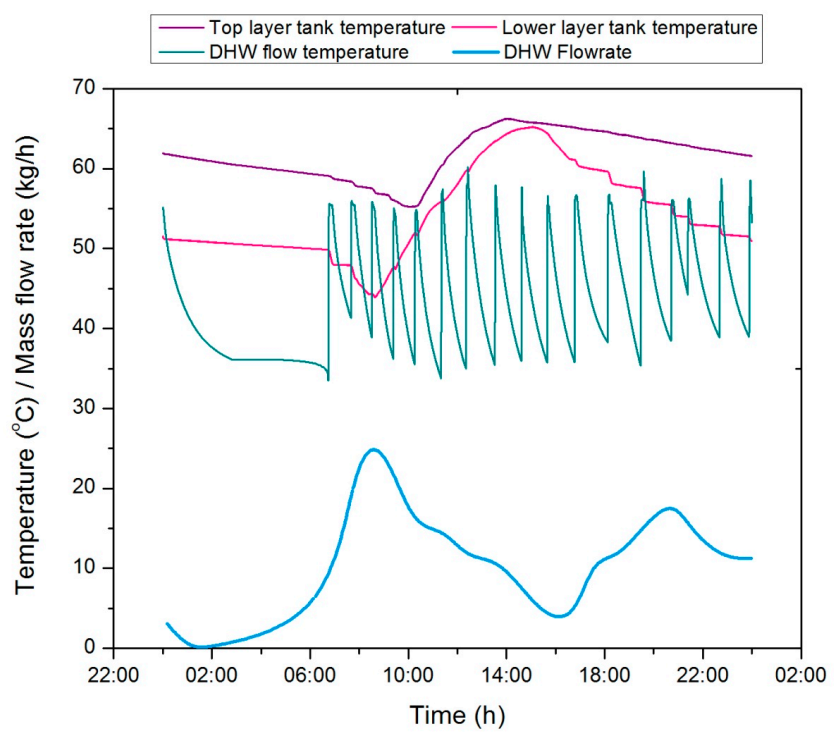

Figure 14. Twenty-four-hour operation profile of DHW preparation.

\subsubsection{Performance Variation with DHW Withdrawal Rate}

Performance of the solar cogeneration system is analyzed by doubling the domestic hot water withdrawal rate as shown Figure 15. Although theoretical demand of hot water for single family of five is $250 \mathrm{~L} /$ day [31], some studies in UAE reveals that each person would consume $120 \mathrm{~L} /$ day of hot water [36]. Investigation is conducted with eight solar collectors integrated with solar cogeneration system with useful energy gain of $50 \mathrm{~kW}$. In terms of distillate production, daily productivity is reduced by $6 \%$ due higher hot water withdrawal. Temperature profiles of DHW tank top layer and MD hot water inlet temperatures are shown in Figure 13. Hot water supplied to MD with 250 L DHW withdrawal is slightly higher than the $500 \mathrm{~L}$ DHW withdrawal testing, which leads to higher distillate productivity with lower DHW withdrawal. During $24 \mathrm{~h}$, the DHW hot water tank temperature profile varies between $55^{\circ} \mathrm{C}$ and $70{ }^{\circ} \mathrm{C}$ throughout the operation. This investigation proves that solar cogeneration system integrated with eight solar collectors is capable of providing $23 \mathrm{~kg} /$ day of potable water and $500 \mathrm{~L} /$ day of domestic hot water. 


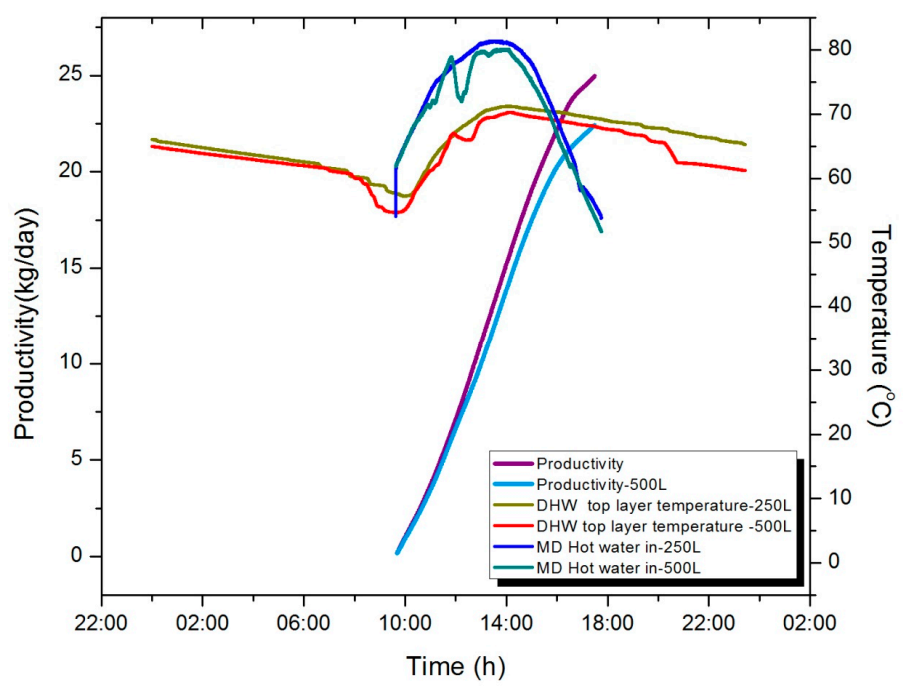

Figure 15. Performance variation of SCMD with two different DHW withdrawal rates.

\subsubsection{Performance Variation between Standalone MD and Co-Production}

Solar cogeneration system is developed with a flexibility to operate as standalone MD without DHW production. Operational performance of standalone MD system is compared with solar cogeneration system is shown in Figure 16 (operated on two consecutive days with similar weather conditions). SCMD integrated with five solar collectors to analyze the performance of system in both cogeneration and standalone modes. MD hot water inlet temperature varies between $84{ }^{\circ} \mathrm{C}$ and $50{ }^{\circ} \mathrm{C}$ during standalone operation. Maximum distillate production of $4.5 \mathrm{~kg} / \mathrm{h}$ at 13:00 h is achieved with standalone operation, which is $36 \%$ higher than solar cogeneration configuration. In terms of daily productivity, a total of $26 \mathrm{~kg}$ of potable water is obtained with 8-h operation. Whereas, daily productivity of $19 \mathrm{~kg}$ of potable water is achieved with solar cogeneration plant which is $27 \%$ lower than standalone system. Energy consumed by standalone MD system is $26 \mathrm{~kW}$ out of $33.8 \mathrm{~kW}$ total useful energy, whereas $18.5 \mathrm{~kW}$ of thermal energy is consumed by MD and $7.3 \mathrm{~kW}$ of thermal energy is utilized for DHW preparation out of $31 \mathrm{~kW}$ useful collector gains. In terms of system efficiencies, solar cogeneration system has 5\% higher efficiency than standalone MD system operation.

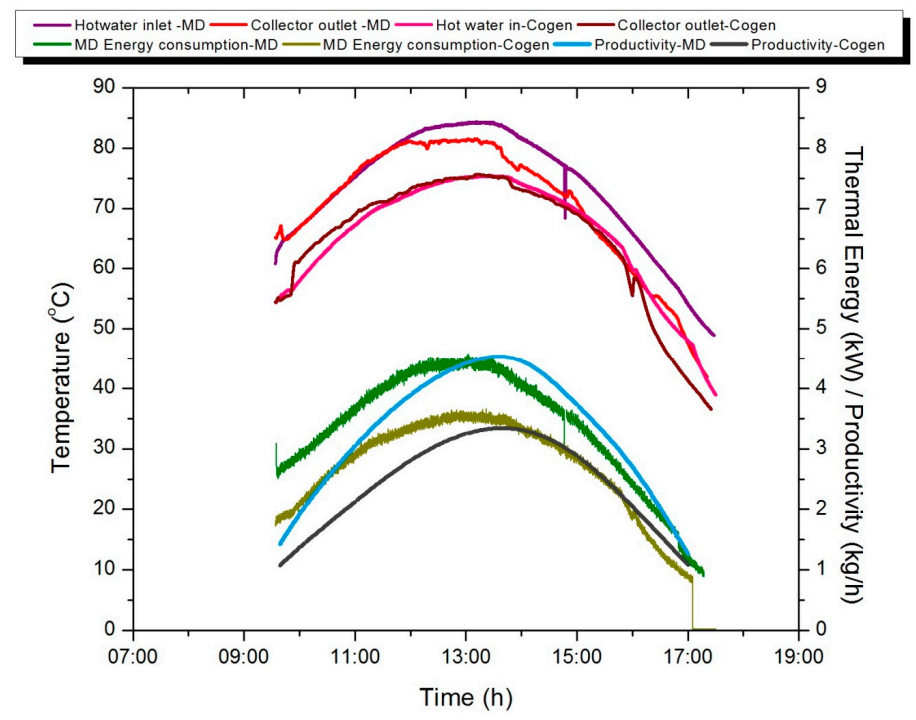

Figure 16. Comparison between standalone MD and co-generation. 


\subsubsection{Effect of Collector Area and Storage Volume}

The system performance of solar cogeneration unit is evaluated with different collector area and storage volume in this section. Collector area is varied in terms of number of collectors integrated with the system. Operational performance of solar cogeneration system is evaluated with four different collector integrations: three collectors $\left(7.65 \mathrm{~m}^{2}\right)$, five collectors $\left(12.75 \mathrm{~m}^{2}\right)$, six collectors $\left(15.3 \mathrm{~m}^{2}\right)$ and eight collectors $\left(20.4 \mathrm{~m}^{2}\right)$. In terms of distillate production, a maximum potable water of $25 \mathrm{~kg} /$ day is achieved with eight-collectors integrated, which is $54 \%$ higher than three-collector mode, as shown in Figure 17. It is possible to achieve $250 \mathrm{~L}$ of DHW at $55{ }^{\circ} \mathrm{C}$ with all collector integrations, except for three-collector integration. Further, the effect of storage volume on the performance of solar cogeneration system is analyzed with two different tanks with $500 \mathrm{~L}$ and $300 \mathrm{~L}$ capacities. Distillate productivity of solar cogeneration system with $300 \mathrm{~L}$ tank is improved by $6.7 \%$ compared to $500 \mathrm{~L}$ thermal store integration, which is mainly due to lesser charging period with $300 \mathrm{~L}$ thermal store. Based on results, cogeneration system integrated with five solar collectors and $300 \mathrm{~L}$ thermal store produces potable water close to $20 \mathrm{~kg} /$ day and $250 \mathrm{~L}$ of domestic hot water, which is ideally suited for single family house in UAE.

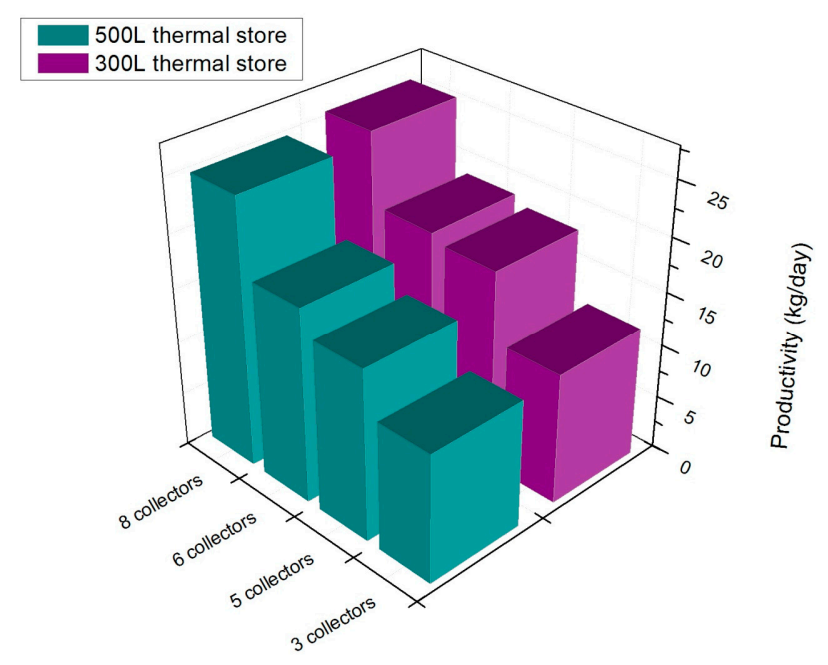

Figure 17. Distillate productivity with different collector area and storage volume.

\subsection{TRNSYS Dynamic Simulation}

\subsubsection{Experimental Validation of SCMD System}

Thermal performance of integrated SDHW and SMD system designed to provide required DHW and pure water demand is analyzed through TRNSYS dynamic simulations. One of our previous works provides details of simulation model along with techno-economic assessment of SCMD system [17]. The temperature and energy flows of the simulated SCMD system and its comparison with experimental data for a peak energy utilization day in October are shown in Figures 18 and 19.

As shown Figure 18, for a 5 FPC configuration, TES volume of $500 \mathrm{~L}$ and with DHW production at $50{ }^{\circ} \mathrm{C}$ collector outlet temperatures reached $90{ }^{\circ} \mathrm{C}$ with a $10{ }^{\circ} \mathrm{C}$ drop for MD hot inlet temperatures. The simulation model has been provided with all specifications including the tank losses and MD system circuit losses in order to match experimental performance. Cold water temperature profile for MD is provided based on experimental investigation which would increase by $2.5^{\circ} \mathrm{C}$ from the ambient temperatures. Dynamic simulation results are validated with experimental data and the profiles are in good agreement. Average peak distillate flow of $3 \mathrm{~L} / \mathrm{h}$ was obtained during noon with a total cumulative production of $19 \mathrm{~kg} /$ day. Similar trends have been observed for energy utilization of SCMD shown in Figure 19. Combined efficiency, which is the ratio of all the useful work from 
membrane distiller $\left(Q_{M D}\right)$ and domestic hot water supply $\left(Q_{D H W}\right)$ to the incident solar energy $\left(\mathrm{I}_{\mathrm{Col}}\right)$, reaches a peak of $50 \%$ at noon. Out of the total incident energy of $60 \mathrm{~kW}, 27 \%$ of energy is utilized for MD and $8.5 \%$ is utilized for DHW operation. Total system efficiency of $80 \%$ is achieved, which is defined as the ratio of total energy from membrane distiller $\left(Q_{M D}\right)$ and domestic hot water supply $\left(Q_{D H W}\right)$ to the total useful energy (Gain from collectors $Q_{\mathrm{Col}}+$ Heat exchanger rate $\left.Q_{H X \text { rate }}\right)$.

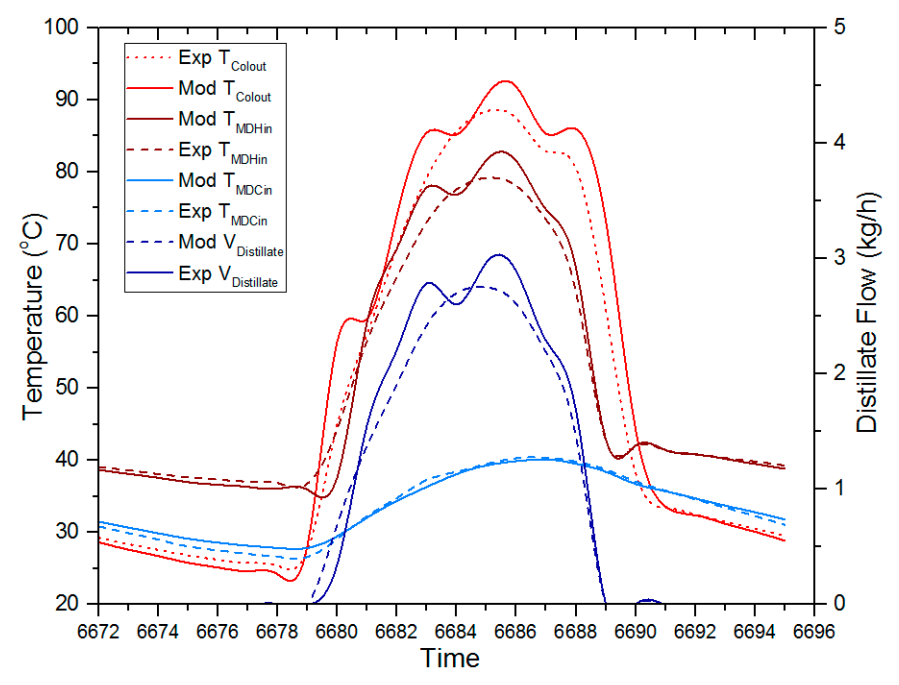

Figure 18. Temperature profiles and distillate flow in SCMD.

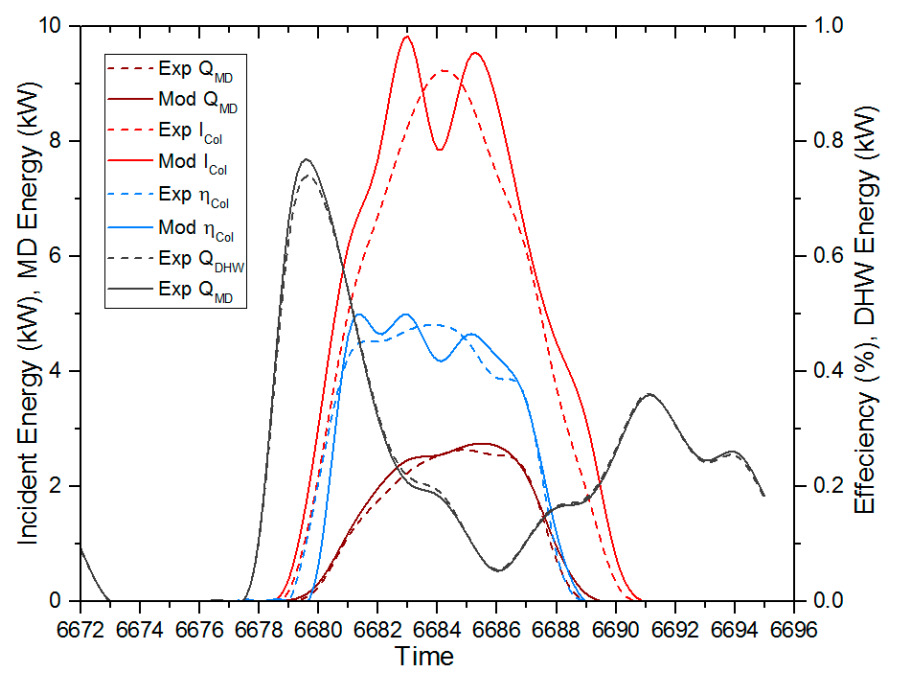

Figure 19. Incident radiation, energy flows and efficiency of SCMD.

\subsubsection{Annual Simulation of Individual and SCMD Systems}

In order to compare the SCMD performance dynamics with individual operation, SDHM and SMD systems have been simulated initially. Annual simulation results of a solar domestic hot water system (SDHW) installed in UAE conditions, which is designed to have an annual solar fraction of 0.90, are shown Figure 20. Two flat plate collectors with $5.1 \mathrm{~m}^{2}$ gross area are simulated at a tilt angle of $35^{\circ}$ which maximizes the winter DHW demand fulfillment. Peak temperature for storage tank reached in the month of October and lowest in December. For a family of five persons in this region, total DHW annual energy consumption would be around $2100 \mathrm{~kW}$ including the auxiliary heating. An annual average collector efficiency of $43 \%$ could be obtained with lowest efficiency in May and highest in December. 


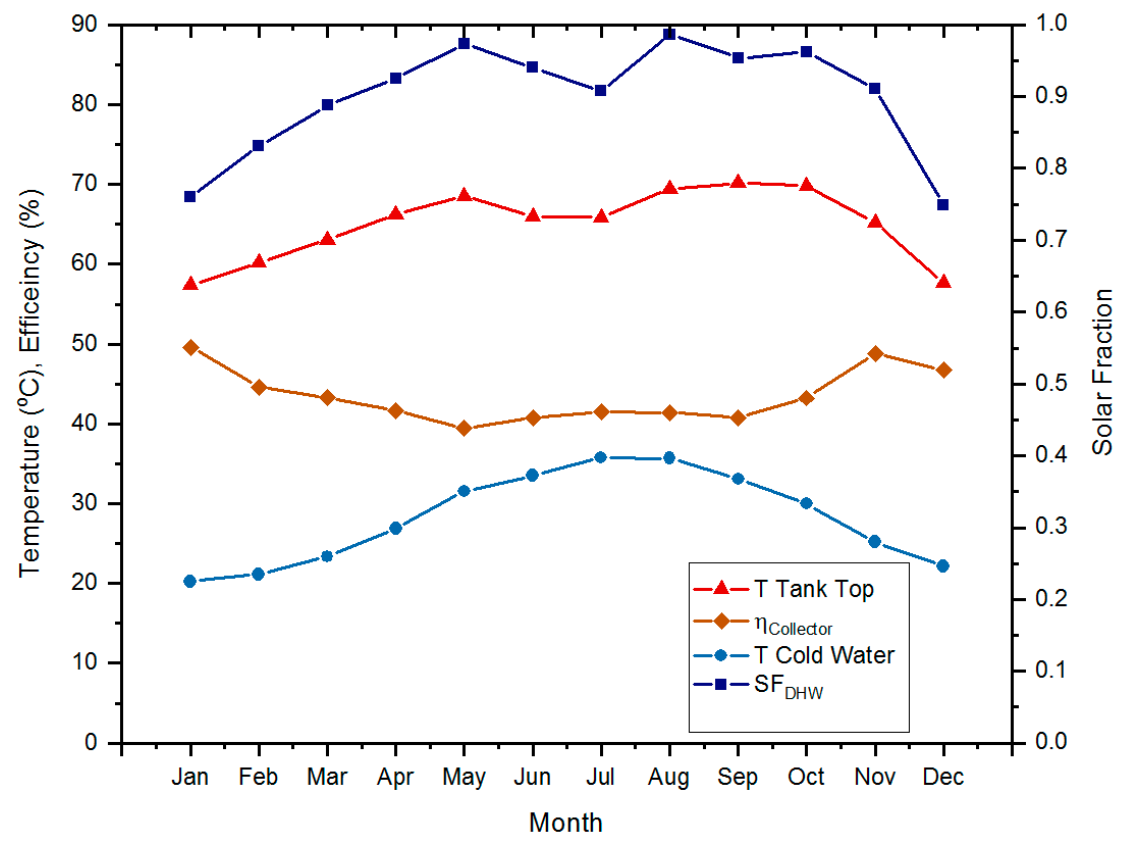

Figure 20. Annual simulation of typical SDHW system in UAE.

Similarly, annual performance of standalone operation of solar membrane distillation (SMD) is shown in Figure 21. Direct integration to solar thermal loop enables maximum utilization of absorbed solar heat energy in SMD system. Simulation of SMD system using three flat plate collectors maintained at similar tilt of $35^{\circ}$ shows that an average solar fraction of 0.88 could be achieved. Desired production of $20 \mathrm{~L} /$ day of pure water could not be fulfilled during winter and peak summer months. This is due to increases in cold water temperatures in summer thus decreasing driving force (delta $\mathrm{T}$ between $\mathrm{T}_{\mathrm{Hin}}$ and $\mathrm{T}_{\mathrm{Cin}}$ ). Delta $\mathrm{T}$ varied from $25^{\circ} \mathrm{C}$ in summer months to $35^{\circ} \mathrm{C}$ in winter. A total of $6440 \mathrm{~kW}$ of heat energy is delivered through the heat exchanger to MD operating at $6 \mathrm{~L} / \mathrm{min}$ of feed flow. Average collector efficiency of $39 \%$ was obtained which is $10 \%$ less efficient when compared with SDHW operation.

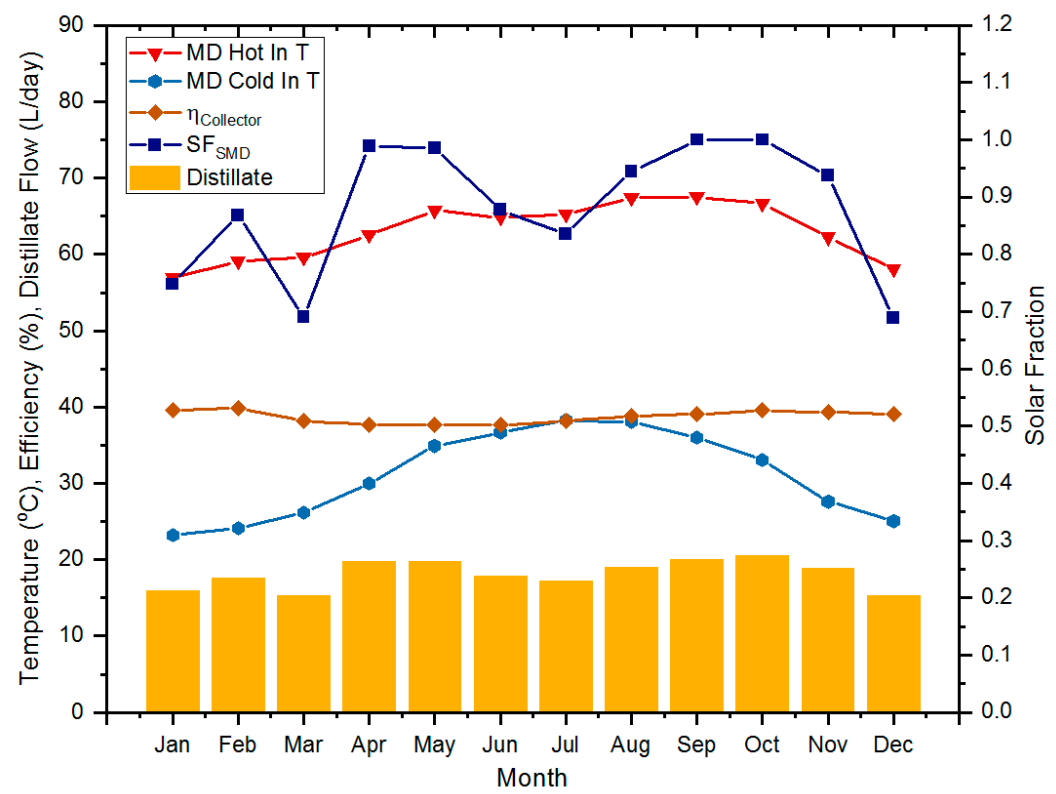

Figure 21. Annual simulation of SMD system operated in UAE. 
Annual simulations has been performed on SCMD system for the existing system configuration of 5 FPC as shown in Figure 22 and obtained annual average co-generation solar fraction $\left(\mathrm{SF}_{\mathrm{Cogen}}\right)$ of 0.91 which is the combined solar fraction of $\mathrm{MD}$ and $\mathrm{DHW}$. For the month of October $\mathrm{SF}_{\text {cogen }}$ obtained from simulation was 1.0 and it has been proved from the experimental results discussed previously. DHW tank temperatures are maintained at an average of $67^{\circ} \mathrm{C}$ which makes the SCMD system to operate with DHW solar fraction of 1.0. For the MD system delta $\mathrm{T}$ of $25-35^{\circ} \mathrm{C}$ was maintained throughout the year with total distillate production of $6850 \mathrm{~L} /$ year. Table 5 shows the comparative annual simulation data for individual and co-production systems. SCMD system efficiency has been increased by $8 \%$ and $20 \%$ compared with individual operation of SDHW and SMD systems respectively.

Table 5. Comparative system analysis based on annual simulation data.

\begin{tabular}{ccccccc}
\hline System & $\begin{array}{c}\text { Collector } \\
\text { Area }\end{array}$ & $\begin{array}{c}\text { Avg. TES } \\
\text { Top T }\end{array}$ & $\begin{array}{c}\text { Avg. MD } \\
\text { Hoi In T }\end{array}$ & $\begin{array}{c}\text { Avg. Distillate } \\
\text { Production }\end{array}$ & $\begin{array}{c}\text { Avg. Collector } \\
\text { Efficiency }\end{array}$ & $\begin{array}{c}\text { Solar } \\
\text { Fraction }\end{array}$ \\
\hline SDHW & $5.1 \mathrm{~m}^{2}$ & $65{ }^{\circ} \mathrm{C}$ & - & - & $43.4 \%$ & 0.90 \\
SMD & $7.65 \mathrm{~m}^{2}$ & - & $63^{\circ} \mathrm{C}$ & $18 \mathrm{~L} /$ day & $38.7 \%$ & 0.88 \\
SCMD & $12.75 \mathrm{~m}^{2}$ & $66.5^{\circ} \mathrm{C}$ & $62^{\circ} \mathrm{C}$ & $18.7 \mathrm{~L} /$ day & $47 \%$ & 0.91 \\
\hline
\end{tabular}

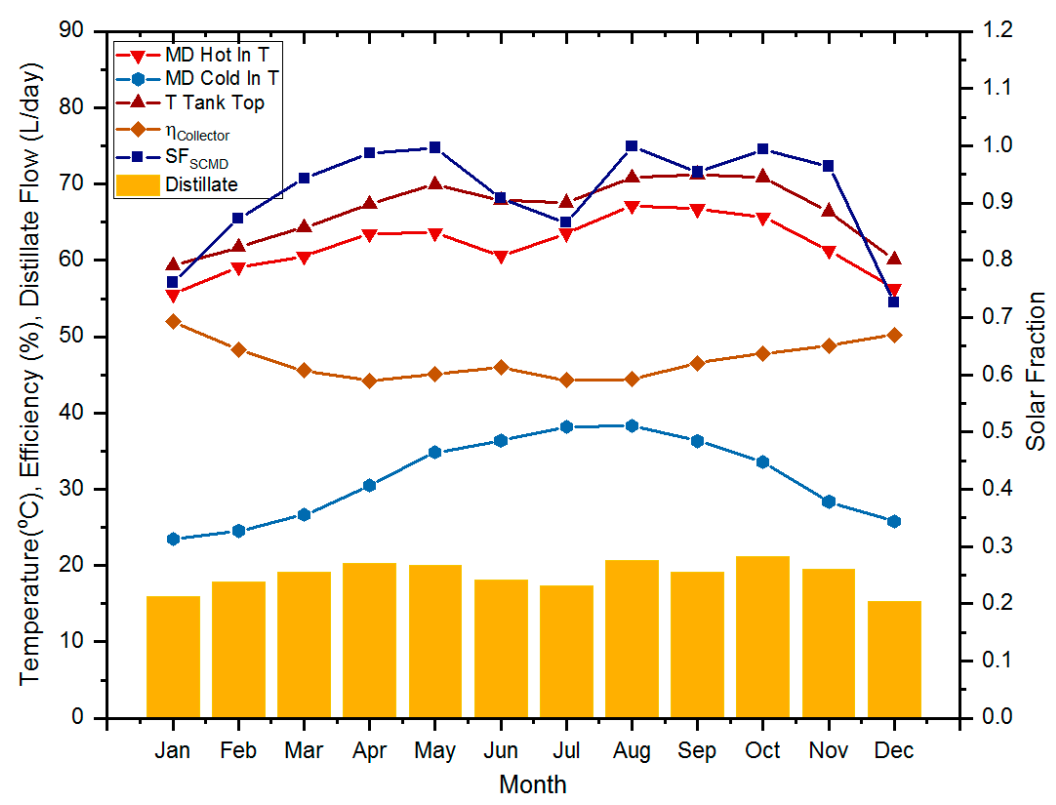

Figure 22. Annual simulation of SCMD system for co-production.

\section{Concluding Remarks}

Experimental investigation of a novel solar combi membrane distillation (SCMD) system is essential to prove its feasibility for co-generation of pure water and domestic hot water. A pilot system, designed for decentralized water production and experimentally investigated, produces pure distillate having conductivities of less than $10 \mu \mathrm{S} / \mathrm{cm}$. With addition of a suitable post-mineralization system, the SCMD system could serve the purpose of point of use water treatment device operated in a sustainable way. Individual system performances were analyzed for only solar hot water and pure water using membrane distillation and an integrated system with two different modes were analyzed.

Thermal store integration has few limitations in terms of feed line pressure fluctuations and limited scope of selection in storage tanks. Hence, research focus has been shifted to direct solar integrated SCMD system. Since MD process requires higher temperatures than DHW, solar thermal heat must be supplied in series to MD feed tank first and then to DHW store. This type of integration 
is essential to maintain low pressures in MD hot channel; otherwise, cassette could leak if integrated directly to thermal store as in the case of STSMD. Intermediate thermal store for MD feed leads to delay of startup time of MD but it could be compensated by extending operational hours after switching off solar energy supply using the energy stored in small buffer tank. However, advantage of nighttime operation using large TES with STSMD mode would be compromised using SCMD. Therefore, careful attention has to be given in designing such co-generation systems in case of continuous operation.

Brief experimental studies shows that solar cogeneration system has $5 \%$ higher system efficiency than standalone MD system. Compared to thermal store integrated system STSMD, 6-7\% increase in MD energy usage is observed with direct solar combi system SCMD. For same collector area, 6-7\% increase in distillate production is observed with decreasing TES volume from $520 \mathrm{~L}$ to $300 \mathrm{~L}$. In SCMD system, distillate productivity is decreased by only $6 \%$ with twofold increase of DHW. This is because of high thermal energy input utilizing the entire flat plate collector field of $20 \mathrm{~m}^{2}$. Experiments conducted during peak thermal energy supply months for $35^{\circ}$ tilt angle of FPC suggests that demand conditions for distillate production of $20 \mathrm{~L} /$ day, DHW $250 \mathrm{~L} /$ day at $50{ }^{\circ} \mathrm{C}$ would be achieved with five flat plate collectors and $300 \mathrm{~L}$ thermal storage tank.

Further experimental investigations on SCMD system are validated using TRNSYS simulation model, which can be operated at $80 \%$ system efficiency. Annual dynamic simulation results shows that combined operation of SDHW and SMD would increase collector efficiencies and also higher solar fraction could be achieved. Average distillate production could also be increased marginally using SCMD system along with complete energy supply for DHW operation.

Author Contributions: Nutakki Tirumala Uday Kumar conceived, designed, performed the experiments, analyzed the data and wrote the paper; Andrew R. Martin contributed for material supply and supervised the research work.

Conflicts of Interest: The authors declare no conflict of interest.

\section{References}

1. Mezher, T.; Fath, H.; Abbas, Z.; Khaled, A. Techno-economic assessment and environmental impacts of desalination technologies. Desalination 2011, 266, 263-266. [CrossRef]

2. SCAD.AE. Available online: https://www.scad.ae/_ws/dlSpFile.ashx?_fn=/Release\%20Documents/ Energy\%20and\%20Water\%202014-En-v4.pdf (accessed on 25 October 2016).

3. Fitnesslink.ae. Available online: https://fitnesslink.me/articles/488/a-study-of-tap-water-vs-bottledwater-in-the-uae (accessed on 25 October 2016).

4. Bottledwater.Org. Available online: http://www.bottledwater.org/public/BWR\%20JulyAug\%202015\% 20Issue_BMC_2014\%20Bottled\%20Water\%20Statistics\%20Article.pdf\#overlay-context=economics / industry-statistics (accessed on 25 October 2016).

5. Karagiannis, L.C.; Soldatos, P.G. Water desalination cost literature: Review and assessment. Desalination 2008, 223, 448-456. [CrossRef]

6. Gleick, P.H.; Cooley, H.S. Energy implications of bottled water. Environ. Res. Lett. 2009, 4, 014009. [CrossRef]

7. Qtaishat, M.R.; Banat, F. Desalination by solar powered membrane distillation systems. Desalination 2013, 308, 186-197. [CrossRef]

8. Lucy, M.C.; Ludovic, D.; Jianhua, Z.; Jun-de, L.; Mikel, D.; Juan, G.; Stephen, G. Advances in Membrane Distillation for Water Desalination and Purification Applications. Water 2013, 5, 94-196.

9. Banat, F.; Jwaied, N.; Rommel, M.; Koschikowski, J.; Wieghaus, M. Desalination by a "compact smades" autonomous solarpowered membrane distillation unit. Desalination 2007, 217, 29-37. [CrossRef]

10. Koschikowski, J.; Wieghaus, M.; Rommel, M.; Ortin, V.S.; Suarez, B.P.; Betancort, J.R. Experimental investigations on solar driven stand-alone membrane distillation systems for remote areas. Desalination 2009, 248, 125-131. [CrossRef]

11. Banat, F.; Jwaied, N. Autonomous membrane distillation pilot plant unit driven solar energy: Experiences and lessons learned. Int. J. Sustain. Water Environ. Syst. 2010, 1, 21-24. [CrossRef] 
12. Blanco Gálvez, J.; García-Rodríguez, L.; Martín-Mateos, I. Seawater desalination by an innovative solar-powered membrane distillation system: The MEDESOL project. Desalination 2009, 246, 567-576. [CrossRef]

13. Guillén-Burrieza, E.; Blanco, J.; Zaragoza, G.; Alarcón-Padilla, D.C.; Palenzuela, P.; Ibarra, M.; Gernjak, W. Experimental analysis of an air gap membrane distillation solar desalination pilot system. J. Membr. Sci. 2011, 379, 386-396. [CrossRef]

14. Guillén-Burrieza, E.; Alarcón-Padilla, D.C.; Palenzuela, P.; Zaragoza, G. Techno-economic assessment of a pilot-scale plant for solar desalination based on existing plate and frame MD technology. Desalination 2015, 374, 70-80. [CrossRef]

15. Saffarini, R.B.; Summers, E.K.; Arafat, H.A.; Lienhard, V.J.H. Economic evaluation of stand-alone solar powered membrane distillation systems. Desalination 2012, 299, 55-62. [CrossRef]

16. Horta, P.; Zaragoza, G.; Alarcón-Padilla, D.C. Assessment of the use of solar thermal collectors for desalination. Desalination Water Treat. 2015, 55, 2856-2867. [CrossRef]

17. Kumar, N.T.U.; Martin, A. Simulation and Economic Analysis of Solar Thermal Cogeneration System for Production of Heat and Pure Water using Membrane Distillation. Int. J. Therm. Environ. Eng. 2016, 11, $33-39$.

18. Calise, F.; Palombo, A.; Vanoli, L. Maximization of primary energy savings of solar heating and cooling systems by transient simulations and computer design of experiments. Appl. Energy 2010, 87, 524-540. [CrossRef]

19. Buonomano, A.; Calise, F.; d'Accadia, M.D.; Vanoli, L. A novel solar trigeneration system based on concentrating photovoltaic/thermal collectors. Part 1: Design and simulation model. Energy 2013, 61, 59-71. [CrossRef]

20. Liu, C.; Martin, A. Applying Membrane Distillation in High-Purity Water Production for Semiconductor Industry. Ultrapure Water 2006. Available online: www.xzero.se/doc/chuanfeng\%26martin-final-20051014. pdf (accessed on 1 April 2017).

21. Kullab, A.; Martin, A. Membrane distillation and applications for water purification in thermal cogeneration plants. Sep. Purif. Technol. 2011, 76, 231-237. [CrossRef]

22. Khan, U.E.; Mainali, B.; Martin, A. Techno-economic analysis of small scale biogas based polygeneration systems: Bangladesh case study. Sustain. Energy Technol. Assess. 2014, 7, 68-78. [CrossRef]

23. Ershad, U.K.; Martin, A. Optimization of hybrid renewable energy polygeneration system with membrane distillation for rural households in Bangladesh. Energy 2015, 93, 1116-1127.

24. Mohan, G.; Dahal, S.; Kumar, N.T.U.; Martin, A.; Kayal, H. Development of Natural Gas Fired Combined Cycle Plant for Tri-Generation of Power, Cooling and Clean Water Using Waste Heat Recovery: Techno-economic analysis. Energies 2014, 7, 6358-6381. [CrossRef]

25. Mohan, G.; Kumar, N.T.U.; Pokhrel, M.K.; Martin, A. A Novel solar thermal polygeneration system for sustainable production of cooling, clean water and domestic hot water in United Arab Emirates: Dynamic simulation and economic evaluation. Appl. Energy 2016, 167, 173-188. [CrossRef]

26. Mohan, G.; Kumar, N.T.U.; Pokhrel, M.K.; Martin, A. Experimental investigation of a novel solar thermal polygeneration plant in United Arab Emirates. Renew. Energy 2016, 91, 361-373. [CrossRef]

27. Kumar, N.T.U.; Martin, A. Co-generation of Drinking Water and Domestic Hot Water Using Solar Thermal Integrated Membrane Distillation System. Energy Procedia 2014, 61, 2666-2669. [CrossRef]

28. Asim, M.; Kumar, N.T.U.; Martin, A. Feasibility analysis of solar combi-system for simultaneous production of pure drinking water via membrane distillation and domestic hot water for single-family villa: Pilot plant setup in Dubai. Desalination Water Treat. 2016, 57, 21674-21684. [CrossRef]

29. Zhangyuan, W.; Wansheng, Y.; Feng, Q.; Xiangmei, Z.; Xudong, Z. Solar water heating: From theory, application, marketing and research. Renew. Sustain. Energy Rev. 2015, 41, 68-84.

30. Sameer, A.; Mutasim, N. Potential of energy and water efficiency improvement in Abu Dhabi's building sector-Analysis of Estidama pearl rating system. Renew. Energy 2015, 82, 100-107.

31. ESTIDAMA, UAE. Available online: http://estidama.upc.gov.ae/estidama-villa-products-database.aspx? lang=en-US (accessed on 25 October 2016).

32. Kumar, N.T.U.; Mohan, G.; Martin, A. Performance analysis of solar cogeneration system with different integration strategies for potable water and domestic hot water production. Appl. Energy 2016, 170, 466-475. [CrossRef] 
33. Cipollina, A.; di Sparti, M.G.; Tamburini, A.; Micale, G. Development of a membrane distillation module for solar energy seawater desalination. Chem. Eng. Res. Des. 2012, 90, 2101-2121. [CrossRef]

34. Ershad, U.K.; Martin, A. Water purification of arsenic-contaminated drinking water via air gap membrane distillation (AGMD). Periodica Polytech. 2014, 58, 47-53.

35. Khayet, M.; Matsura, T. Membrane Distillation: Principle and Applications; Elsevier: Amsterdam, The Netherlands, 2011.

36. Solarthermalworld.Org. Available online: http://www.solarthermalworld.org/content/hot-water-demand120-litres-day-person (accessed on 25 October 2016).

(c)

(C) 2017 by the authors. Licensee MDPI, Basel, Switzerland. This article is an open access article distributed under the terms and conditions of the Creative Commons Attribution (CC BY) license (http:/ / creativecommons.org/licenses/by/4.0/). 